Article

\title{
$\alpha, \alpha$-Difluorophosphonohydroxamic Acid Derivatives among the Best Antibacterial Fosmidomycin Analogues
}

\author{
Aurore Dreneau, Fanny S. Krebs, Mathilde Munier, Chheng Ngov (D), Denis Tritsch, Didier Lièvremont, \\ Michel Rohmer and Catherine Grosdemange-Billiard *
}

Laboratoire de Chimie et Biochimie de Molécules Bioactives, Université de Strasbourg/CNRS, UMR 7177, Institut Le Bel, 4 Rue Blaise Pascal, 67081 Strasbourg, France; aurore.dreneau@gmail.com (A.D.); krebs.fanny@live.fr (F.S.K.); mathilde.munier01@hotmail.fr (M.M.); chheng.ngov@alsace.cnrs.fr (C.N.); tritsch.denis@neuf.fr (D.T.); didier.lievremont@unistra.fr (D.L.); mirohmer@unistra.fr (M.R.)

* Correspondence: grosdemange@unistra.fr; Tel.: +33-368-851-349

Citation: Dreneau, A.; Krebs, F.S.; Munier, M.; Ngov, C.; Tritsch, D.; Lièvremont, D.; Rohmer, M.; Grosdemange-Billiard, C. $\alpha, \alpha$-Difluorophosphonohydroxamic Acid Derivatives among the Best Antibacterial Fosmidomycin Analogues. Molecules 2021, 26, 5111. https://doi.org/10.3390/molecules 26165111

Academic Editors:

Camilla Parmeggiani,

Camilla Matassini and

Francesca Cardona

Received: 28 July 2021

Accepted: 22 August 2021

Published: 23 August 2021

Publisher's Note: MDPI stays neutral with regard to jurisdictional claims in published maps and institutional affiliations.

Copyright: (c) 2021 by the authors. Licensee MDPI, Basel, Switzerland. This article is an open access article distributed under the terms and conditions of the Creative Commons Attribution (CC BY) license (https:/ / creativecommons.org/licenses/by/ $4.0 /)$.

\begin{abstract}
Three $\alpha, \alpha$-difluorophosphonate derivatives of fosmidomycin were synthesized from diethyl 1,1-difluorobut-3-enylphosphonate and were evaluated on Escherichia coli. Two of them are among the best 1-deoxy-D-xylulose 5-phosphate reductoisomerase inhibitors, with $\mathrm{IC}_{50}$ in the $\mathrm{nM}$ range, much better than fosmidomycin, the reference compound. They also showed an enhanced antimicrobial activity against $E$. coli on Petri dishes in comparison with the corresponding phosphates and the non-fluorinated phosphonate.
\end{abstract}

Keywords: $\alpha, \alpha$-difluorophosphonate; deoxyxylulose phosphate reductoisomerase; 1-deoxy-Dxylulose 5-phosphate reductoisomerase (DXR); antimicrobial; fosmidomycin; isoprenoid biosynthesis; 2-C-methyl-D-erythritol 4-phosphate (MEP) pathway

\section{Introduction}

Antimicrobial resistance affecting anyone in any country is rising to dangerously high levels in all parts of the world and has been recognized as a global health crisis by the United Nations and the World Health Organization (WHO). As a result, the antibiotic treatment of a growing number of infections, e.g., tuberculosis, pneumonia, gonorrhea, and salmonellosis, are becoming less and less effective. In 2017, WHO reported a list of twelve priority pathogens, mostly Gram-negative bacteria belonging to e.g., the Enterobacteriaceae or to other groups (e.g., Acinetobacter baumannii, Pseudomonas aeruginosa...) for which it is urgent to find new treatments [1]. Recently, a study of the European Centre for Disease Prevention and Control (ECDPC) estimated that about 33,000 people died each year from an infection due to antimicrobial-resistant bacteria, frequently while receiving health care i.e., from nosocomial infections [2]. It is therefore crucial and urgent to identify new targets in order to elaborate and develop new drugs. In this respect, the biosynthesis of isopentenyl diphosphate (IPP) and dimethylallyl diphosphate (DMAPP), the two precursors of all isoprenoids, via the 2-C-methyl-D-erythritol 4-phosphate (MEP) pathway is an attractive prospect. In fact, this pathway is essential and present in many Gram-negative and Grampositive bacteria as well as protozoans, e.g., Plasmodium species responsible for malaria [3]. As this pathway is absent in humans, each enzyme is a potential target to elaborate new antimicrobial compounds with expected minimal side effects for the patient. Part of our work on the design of new antimicrobials is based on the inhibition of the second enzyme of the MEP pathway, the 1-deoxy-D-xylulose 5-phosphate reductoisomerase (DXR), which catalyzes the conversion of 1-deoxy-D-xylulose 5-phosphate (DXP) 1 into MEP 2 in the presence of a divalent metal ion $\left(\mathrm{Mg}^{2+}\right.$ or $\left.\mathrm{Mn}^{2+}\right)$ and NADPH as cofactors (Scheme 1).

Indeed, fosmidomycin 3a and its $N$-acetyl homologue, FR-900098 3b, two natural retrohydroxamate phosphonic acids isolated from Streptomyces spp., are selective inhibitors of DXR $[4,5]$. However, their use in antibiotherapy is limited due to their fast clearance and 
glycerol 3-phosphate [11]. In fact, the presence of fluorine atoms able to form fluorinehydrogen bonds in the DXR active site could affect the binding properties of the parent compounds and also increase their bioavailability [19]. Moreover, the presence of two fluorine atoms might increase the lipophilic properties of the compounds allowing a better cellular uptake [20]. In this context, the synthesis of the protected gem-difluoro FR-900098 derivative $\mathbf{1 6 b}$ and $\mathrm{N}-\mathrm{H}$ phosphonohydroxamic acid 10a (Scheme 2 ) have been recently reported for a herbicide application [21].

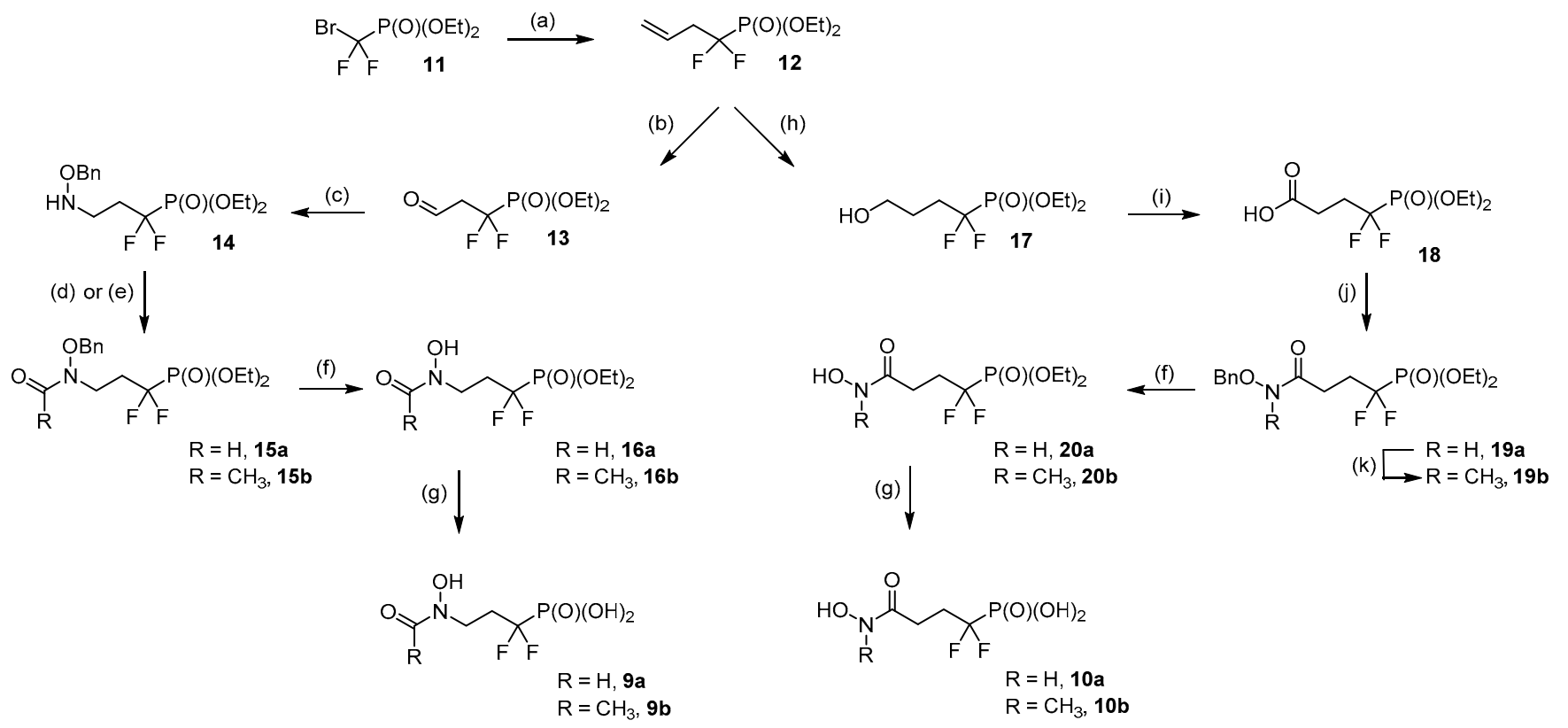

Scheme 2. Synthesis of the $\alpha, \alpha$-difluorophosphonated fosmidomycin derivatives 9 and 10. Reagents and conditions: (a) $\mathrm{Zn}, \mathrm{CuBr}$, then allyl bromide, $\mathrm{DMF}(89 \%)$; (b) (i) $\mathrm{O}_{3}, \mathrm{MeOH}, \mathrm{CH}_{2} \mathrm{Cl}_{2},-78{ }^{\circ} \mathrm{C}$; (ii) $\mathrm{Me}_{2} \mathrm{~S}$, (quantitative); (c) $\mathrm{BnONH}_{2}$. $\mathrm{HCl}$, $\mathrm{NaBH}_{3} \mathrm{CN}, \mathrm{HCl}$ conc, $\mathrm{MeOH}(35 \%)$; (d) $\mathrm{HCOOH} / \mathrm{Ac}_{2} \mathrm{O}, \mathrm{THF}, \mathrm{rt}, 15 \mathrm{a},(83 \%)$; (d) $\mathrm{Ac}_{2} \mathrm{O}$, pyridine, rt, 15b, (80\%); (f) $\mathrm{H}_{2}$, $\mathrm{Pd} / \mathrm{C}, \mathrm{MeOH}, \mathrm{rt}, \mathbf{1 6 a}(74 \%), \mathbf{1 6 b}(80 \%), \mathbf{2 0 a}(41 \%), 20 \mathrm{~b}(65 \%)$; (g) TMSBr, DCM, $0{ }^{\circ} \mathrm{C}$, then $\mathrm{H}_{2} \mathrm{O}, 9 \mathbf{b}$ (quantitative), 10a (quantitative), 10b (quantitative); (h,i) $\mathrm{BH}_{3}$-THF complex (ii) $3 \mathrm{M} \mathrm{NaOH}, \mathrm{H}_{2} \mathrm{O}_{2}$ (39\%); (i) TEMPO, BAIB, $\mathrm{MeCN}, \mathrm{H}_{2} \mathrm{O},(86 \%$ ); (j) CDI, DCM, $1 \mathrm{~h}$, rt, then $\mathrm{BnONH}_{2} \cdot \mathrm{HCl}, \mathrm{Et}_{3} \mathrm{~N}, \mathrm{DCM}$, (77\%); (k) MeI, $\mathrm{K}_{2} \mathrm{CO}_{3}$, acetone, 30 min reflux (73\%).

Our investigations are presently orientated toward the synthesis of $\alpha, \alpha$ difluorophosphonate fosmidomycin derivatives $9 a$ and $9 b$ and their analogues 10a and $10 \mathbf{b}$ to evaluate and determine their effect against $E$. coli DXR in order to develop more potent antimicrobials.

\section{Results}

\subsection{Chemistry}

For the introduction of the fluorine atoms into fosmidomycin $\mathbf{3 a}$ and its analogues $\mathbf{3 b}$ and 4, we followed the procedure of Shibuya [22] to synthesize diethyl 1,1-difluorobut-3enylphosphonate $\mathbf{1 2}$ [22,23], the parent precursor for all described compounds 9 and $\mathbf{1 0}$ (Scheme 2). The key precursor 12 has been prepared by a copper(I) catalyzed coupling reaction of [(diethoxyphosphinyl)difluoromethyl]zinc, formed in situ from the commercially available diethyl bromodifluorophosphonate $\mathbf{1 1}$ and $\mathrm{Zn}$ dust, with allyl bromide. The synthesis of the diethyl $\alpha, \alpha$-difluorophosphonate 14 was achieved by previously reported methods [21]. Formylation with the mixed acetyl/formyl anhydride generated in situ from a formic acid and acetic anhydride mixture led to the $N$-formylated compound 15a, which was obtained as a mixture of conformers due to the restricted rotation around the C-N bond [9,24-26] and the large dipole moment of the C-F bond [27]. Acetylation with a mixture of acetic anhydride and pyridine gave the $N$-acetylated analogue $15 \mathbf{b}$ as previously described [21]. 
The protective benzyl group was removed by catalytic hydrogenolysis with palladium over charcoal at atmospheric pressure and room temperature in methanol giving the deprotected hydroxylamines $\mathbf{1 6 a}$ and $\mathbf{1 6 b}$ as a mixture of conformers. Deprotection of the phosphonate group 16 using 10 equivalents of bromotrimethylsilane in DCM following by hydrolysis at room temperature led $\mathbf{9 b}$ as a mixture of conformers. In these conditions, $\mathbf{9 a}$ could not be obtained but led to a deformylated by-product as previously observed [21].

The key step of the synthesis of the $\alpha, \alpha$-difluorophosphonates $\mathbf{1 0}$ was the coupling reaction of the commercially available hydroxylamine hydrochloride with the carboxylic acid 18. The latter compound was obtained in two steps. Hydroboration-oxidation of the parent precursor 12 in presence of THF complex of $\mathrm{BH}_{3}$ and alkaline hydrogen peroxide gave a mixture of the primary and secondary alcohols in a 7/3 ratio, respectively. After purification by flash chromatography, the primary alcohol 17 was oxidized into the carboxylic acid 18 with 2,2,6,6-tetramethyl-1-piperidinyloxyl (TEMPO) in catalytic proportion in presence of [bis(acetoxy)iodo]benzene [28]. Treatment of the carboxylic acid with $\mathrm{O}$-benzylhydroxylamine hydrochloride in the presence of 1-(3-dimethyl-aminopropyl)-3ethylcarbodiimide and 1-hydroxybenzotriazole hydrochloride in DCM gave the hydroxamic acid derivative 19a [21] as a mixture of conformers. The methyl group was introduced by reaction of 19a with $\mathrm{K}_{2} \mathrm{CO}_{3}$ in acetone under reflux followed by addition of methyl iodide to give $\mathbf{1 9 b}$ as a single conformer. Removal of the protective benzyl groups of $19 a$ and $19 \mathrm{~b}$ was achieved by catalytic hydrogenolysis with palladium over charcoal at atmospheric pressure and room temperature leading to $20 \mathrm{a}$ and $20 \mathrm{~b}$ as a mixture of conformers. TMSBr-mediated deprotection of the $\alpha, \alpha$-difluorophosphonate phosphonohydroxamic acid analogues $\mathbf{2 0}$ in the same conditions as described for $\mathbf{9 b}$ provided the free phosphonate 10. Compounds $10 \mathrm{a}$ and $\mathbf{1 0 b}$ were obtained without further purification as a mixture of conformers.

All $\alpha, \alpha$-difluorophosphonated compounds $\mathbf{9 b}$ and $\mathbf{1 0}$ were tested against His-tagged DXR enzyme of $E$. coli and for growth inhibition against a wild type $E$. coli and fosmidomycinresistant E. coli strain (FosR E. coli) as described previously [9].

\subsection{Biological Activity}

\subsubsection{Inhibition of $E$. coli H6-DXR with compounds $\mathbf{9 b}$ and $\mathbf{1 0}$}

The inhibition potency of $\alpha, \alpha$-difluorophosphonohydroxamic acid derivatives was characterized by their $\mathrm{IC}_{50}$ value that was determined as previously described [8]. Postulating that the $\alpha, \alpha$-difluorophosphonated analogues act as slow binding inhibitors like fosmidomycin, they were pre-incubated with DXR during $2 \mathrm{~min}$ in the presence of NADPH. Residual activity was measured after initiating the enzymatic reaction by addition of DXP. The $\mathrm{IC}_{50}$ values are reported in Table 1.

Table 1. Inhibition of E. coli H6-DXR.

\begin{tabular}{cc}
\hline Compounds & IC $_{\mathbf{5 0}}(\mathbf{n M})$ \\
\hline fosmidomycin, 3a & 42 \\
FR-900098, 3b & 4 \\
$\mathbf{4 a}$ & $180^{* *}$ \\
$\mathbf{4 b}$ & $48^{* *}$ \\
fosfoxacin, 5a & $342^{*}$ \\
$\mathbf{5 b}$ & $77^{*}$ \\
$\mathbf{6 a}$ & $2600^{*}$ \\
$\mathbf{6 b}$ & $46^{*}$ \\
$\mathbf{9 a}$ & - \\
$\mathbf{9 b}$ & 9 \\
$\mathbf{1 0 a}$ & 4600 \\
$\mathbf{1 0 b}$ & 17 \\
\hline
\end{tabular}

Mean from at least 2 different assays. Errors were $<5 \%{ }^{*}$ and ${ }^{* *}$ values obtained from references [9] and [8] respectively. 
The inhibitory concentration was determined by measuring the phosphorus content of the solution by the method of Lowry and Lopez [29]. $N$-methylated $\alpha, \alpha$-difluorophosphonates $\mathbf{9 b}$ and $\mathbf{1 0 b}$ show activity on E. coli DXR in the nanomolar concentration range and appear to be 2.5 to 5 times more efficient inhibitors than the parent compound fosmidomycin $3 a$ $\left(\mathrm{IC}_{50}=9 \mathrm{nM}\right.$ and $17 \mathrm{nM}$ respectively vs. $\left.\mathrm{IC}_{50}=42 \mathrm{nM}\right)$ and slightly less potent inhibitors than FR-900098 3b $\left(\mathrm{IC}_{50}=4 \mathrm{nM}\right)$. The presence of two fluorine atoms in $\alpha, \alpha$ position of the phosphonate group has clearly a positive effect on the affinity of the enzyme for these compounds.

As we have previously reported, except for fosmidomycin 3a, non- $N$-methylated derivatives are weaker inhibitors than the $N$-methylated homologues [9]. In fact, the $\mathrm{N}-\mathrm{H} \alpha, \alpha$-difluorophosphonate 10a is 280 -fold less efficient $\left(\mathrm{IC}_{50}=4600 \mathrm{nM}\right)$ than its $N$ methylated analogue $\mathbf{1 0 b}$ and therefore, the poorest inhibitor among all compounds of the non-methylated series. Those results indicated that the replacement of the methylene group or the oxygen atom by a difluoromethylene group enhances the inhibition potency of the $N$-methylated hydroxamic acid derivatives $\left(4 \mathbf{b}, \mathrm{IC}_{50}=48 \mathrm{nM}\right.$ and $6 \mathbf{b}, \mathrm{IC}_{50}=46 \mathrm{nM}$ vs. $\mathbf{1 0 b}, \mathrm{IC}_{50}=17 \mathrm{nM}$ ) but significantly decreased the inhibition by the N-H analogue 10a.

2.2.2. Growth Inhibition of a Wild Type E. coli and Fosmidomycin Resistant E. coli FosR Strain by Compounds $9 b, \mathbf{1 0 a}, \mathbf{b}$

The antimicrobial activity of $\alpha, \alpha$-difluorophosphonate $\mathbf{9 a}$ and $\mathbf{1 0}$ was determined using the paper disc diffusion method and was compared with the antimicrobial activity of the non-fluorinated phosphonate and phosphate compounds 3,4 et 6 . The diameters of the inhibition zone are given with respect to the amount of inhibitor deposited on the disc (Table 2).

Table 2. E. coli XL1 Blue growth inhibition on LB solid medium.

\begin{tabular}{ccc}
\hline Compounds & nmoles/Disc & Growth Inhibition Zone (mm) \\
\hline fosmidomycin, 3a & 2 & 35 \\
FR-900098, 3b & $2 *$ & $32^{*}$ \\
$\mathbf{4 a}$ & $400^{* *}$ & $12^{* *}$ \\
$\mathbf{4 b}$ & $80^{* *}$ & $30^{* *}$ \\
$\mathbf{6 a}$ & $400^{*}$ & $<10^{*}$ \\
$\mathbf{6 b}$ & $160 *$ & $20^{*}$ \\
$\mathbf{9 b}$ & 2 & 15 \\
$\mathbf{1 0 a}$ & 3 & - \\
$\mathbf{1 0 b}$ & 1.5 & 20 \\
\hline
\end{tabular}

Fosmidomycin, the most efficient growth inhibitors of E. coli, was used as a positive control reference. Except for the $\mathrm{N}-\mathrm{H} \alpha, \alpha$-difluorophosphonate 10a where no inhibition was observed, the $N$-methylated derivatives $9 \mathrm{~b}$ and $10 \mathrm{~b}$ were shown to be quite effective to inhibit bacterial growth (Figure 1A). Similar amounts of $\mathbf{9 b}$ and $\mathbf{1 0 b}$ had to be added to observe the same growth inhibition zones as those observed for fosmidomycin. Not only the $N$-Me $\alpha, \alpha$-difluorophosphonates $9 \mathbf{b}$ and $\mathbf{1 0 b}$ are able to inhibit the DXR in vitro but they are also potent $E$. coli growth inhibitors. Clearly, the presence of the two fluorine atoms in $\alpha$ position of the phosphonate enhances the antimicrobial efficiency of the $N$-methylated phosphonohydroxamic acid. Moreover, we observed in the fosmidomycin 3a inhibition zone, colonies of tolerant bacteria, which did not appear with the difluoro compounds $9 \mathbf{b}$ and $\mathbf{1 0 b}$. These persistent bacteria are known to be able to adapt rapidly to the antibiotic stress, although precise mechanisms are not fully understood [30]. Interestingly, $\alpha, \alpha-$ difluoro compounds $\mathbf{9 b}$ and $\mathbf{1 0 b}$ eliminated this survival ability of the E. coli population. 

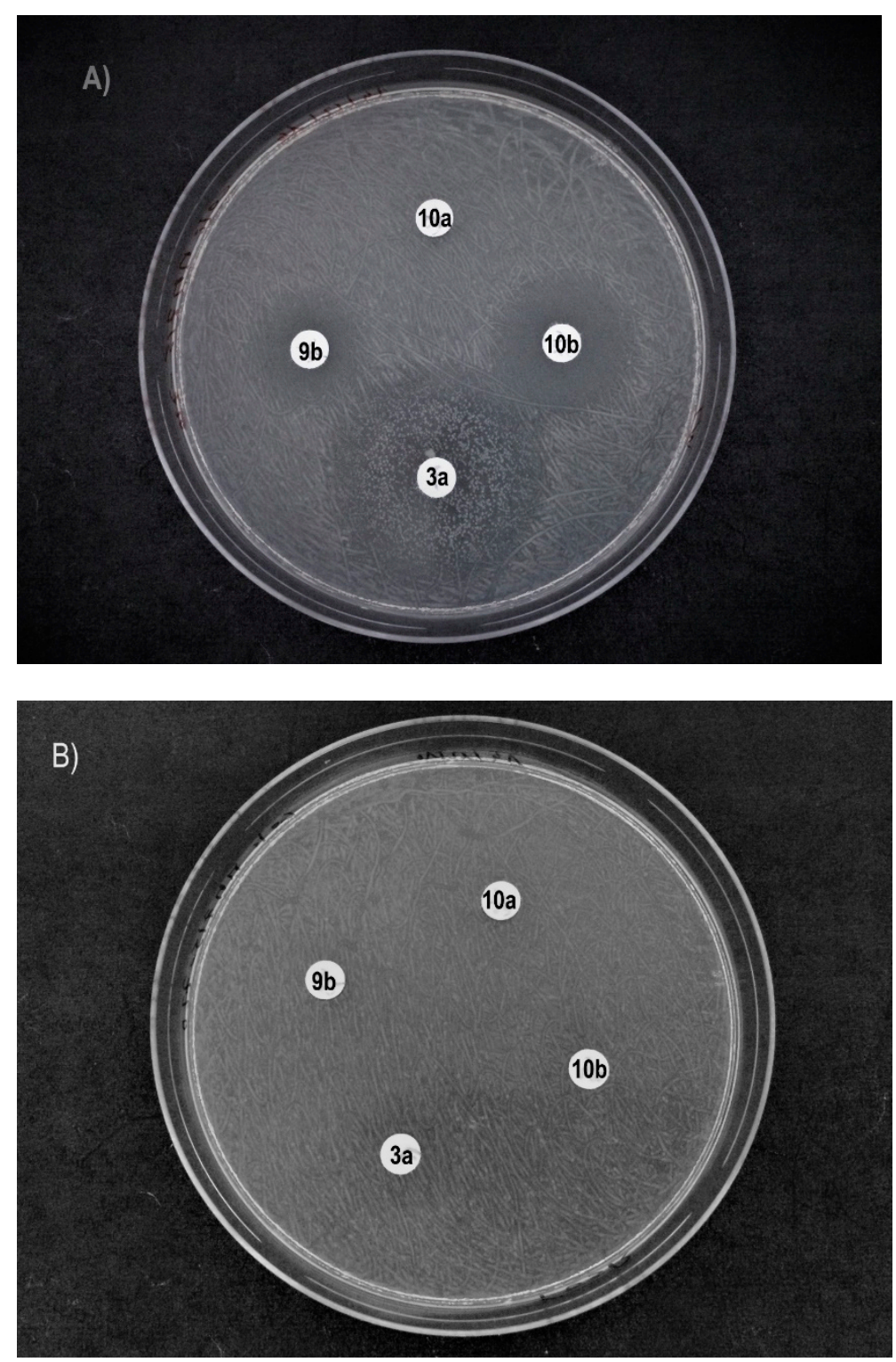

Figure 1. Antimicrobial activity of hydroxamic acids (9b, $2 \mathrm{nM}),(\mathbf{1 0 a}, 3 \mathrm{nM})$ and $(\mathbf{1 0 b}, 1.5 \mathrm{nM})$ compared to fosmidomycin (3a, $2 \mathrm{nM}$ ): (A) against E. coli XL1 Blue; (B) against fosmidomycinresistant strain E. coli FosR.

All DXR $\alpha, \alpha$-difluorophosphonate inhibitors were tested on a fosmidomycin resistant strain of E. coli (FosR), but none of the compounds was able to affect bacterial growth (Figure 1B).

\section{Discussion}

Among a large variety of synthetic analogues of natural phosphono- and phosphoretrohydroxamic acids, e.g., fosmidomycin 3a, FR-900098 $\mathbf{3 b}$ and fosfoxacin $\mathbf{5 a}$, only the $\mathrm{N}$-H gem-difluoro 10a have been reported and evaluated as herbicide [21]. However, Van Calenbergh and co-workers observed that the racemic monofluoro analogues 7 and 8 were more active than the parent compounds fosmidomycin and $\mathbf{4 b}$ against intraerythrocytic forms of Plasmodium falciparum (K1 strain). Interestingly, none of them have been tested against bacteria [14]. Such promising results prompted us to evaluate the efficiency of $\alpha, \alpha$-difluorophosphonate analogues of FR-900098 and its phosphonohydroxamic acid derivatives 10a and $10 \mathbf{b}$ against $E$. coli. Except for the $\mathrm{N}-\mathrm{H} \alpha, \alpha$-difluorophosphononate $10 \mathbf{a}$, the $\mathrm{N}$-methylated $\mathrm{CF}_{2}$-phosphonates $9 \mathbf{b}$ and $\mathbf{1 0 b}$ exhibited stronger inhibition activity 
than that of the reference compound fosmidomycin against $E$. coli DXR. With an $\mathrm{IC}_{50}$ value of $17 \mathrm{nM}$, the $N$-methyl $\alpha$, $\alpha$-difluorophosphono hydroxamic acid $10 \mathrm{~b}$ represents the most powerful inhibitor compared to the non-fluorinated $4 \mathrm{~b}\left(\mathrm{IC}_{50}=48 \mathrm{nM}\right)$ and phosphate $\mathbf{6 b}\left(\mathrm{IC}_{50}=46 \mathrm{nM}\right)$ analogues. Even if the activity of the $\mathrm{CF}_{2}-\mathrm{FR}-900098$ derivative $\mathbf{9 b}$ $\left(\mathrm{IC}_{50}=9 \mathrm{nM}\right)$ is two-fold less active than the parent compound $3 \mathbf{b}\left(\mathrm{IC}_{50}=4 \mathrm{nM}\right)$, it remains a better inhibitor of the $E$. coli DXR than its phosphate derivative $5 \mathbf{b}\left(\mathrm{IC}_{50}=77 \mathrm{nM}\right)$.

The introduction of the two electron-withdrawing fluorine atoms on the $\alpha$-methylene group of the phosphonate significantly decreases the $\mathrm{pKa} 2$ from 7.6 for the phosphonate to ca. 5.4. The $\alpha, \alpha$-difluorophosphonates should therefore be in the dianionic form at the $\mathrm{pH}$ of the enzyme assay much like a phosphate $(\mathrm{pKa} 2=6.4)$, thereby favoring a more efficient binding than the phosphonate, which is mostly in the singly ionized form. In addition, the dihedral $\mathrm{C}-\mathrm{CF}_{2}-\mathrm{P}$ angle $\left(116.1^{\circ}\right)$, wider than the $\mathrm{C}-\mathrm{CH}_{2}-\mathrm{P}\left(112.1^{\circ}\right)$, closely resembles that of the phosphate C-O-P angle of $118.7^{\circ}$ [12]. The $\alpha, \alpha$-difluorophosphonates were, however, shown to be better inhibitors than the phosphate analogues, resulting in a better setting in the E. coli DXR active site. The performance of the $\alpha, \alpha$-difluorophosphonate analogues cannot thus be attributed to ionization or geometry and could be mostly due to favorable modifications of the electrostatic and van der Waals interactions, leading to an increase of the affinity for those inhibitors.

Compared to the $N$-methylated phosphonate and phosphate, the $\mathrm{CF}_{2}$-phosphonates $9 \mathrm{~b}$ and $\mathbf{1 0 b}$ inhibited efficiently the growth of E. coli at doses similar to those of fosmidomycin and FR-900098, making them powerful promising antimicrobials. It is generally accepted that introduction of fluorine atoms enhances the lipophilicity of the compounds, which might facilitate a passive diffusion across the cell membrane of the $\alpha, \alpha-$ difluorophosphonate inhibitors. However, we recently reported that, except for the phosphonate $4 \mathrm{~b}$, all phosphate compounds 5 and 6 penetrated into the bacteria via the same transporters as those involved in the transport of e.g., the glycerol 3-phosphate and the hexose 6-phosphate like fosmidomycin and FR-900098 [9]. No growth inhibition by the $\alpha, \alpha$-difluoro phosphonates $\mathbf{9 b}$ and $\mathbf{1 0}$ against fosmidomycin resistant strain E. coli (FosR), in which the GlpT/UhpT transporters are therefore inoperative, was observed implying that these inhibitors penetrate into the bacteria via these transporters (Figure 1B).

In summary, three $\alpha, \alpha$-difluorophosphonate derivatives of fosmidomycin 3a were synthesized and were shown, except for the N-H difluoro compound 10a, to be powerful inhibitors against E. coli DXR. Among the series of hydroxamic acids derivatives, the inhibitor $\mathbf{1 0 b}$ surpasses the phosphonate and phosphate analogues in the inhibition of DXR enzyme as well as in the antimicrobial activity. For $N$-Me difluorophosphonate $\mathbf{9 b}$ and 10b, there is a direct relation between the capacity to inhibit the DXR and the bacterial growth. An important outcome of this study is that the introduction of two fluorine atoms on the $\alpha$-methylene group, favors the inhibition on the DXR and enhances the antimicrobial activity in comparison with the phosphates and the non-fluorinated phosphonates.

\section{Materials and Methods}

\subsection{Chemistry \\ 4.1.1. General Methods}

All non-aqueous reactions were run in oven-dried glassware under an argon atmosphere, using dry solvents. Commercial grade reagents were purchased from SigmaAldrich, Acros Organics or Thermo Fischer Scientific and used without further purification. Petroleum ether (PE) 40-60 ${ }^{\circ} \mathrm{C}$ (Sigma-Aldrich, St-Louis, MO, USA) was used for chromatography. Flash chromatography was performed on silica gel 60 230-400 mesh with the solvent system as indicated. TLC plates were revealed under UV light (254 nm) and/or by spraying with an ethanolic solution of phosphomolybdic acid (20\%) or an ethanolic solution of potassium permanganate followed by heating. The NMR spectra (Supplementary Materials) were recorded on a Bruker Avance $300\left({ }^{1} \mathrm{H}-\mathrm{NMR}: 300 \mathrm{MHz} ;{ }^{13} \mathrm{C}-\mathrm{NMR}\right.$, $\left.75.5 \mathrm{MHz} ;{ }^{31} \mathrm{P}-\mathrm{NMR} 121.5 \mathrm{MHz} ;{ }^{19} \mathrm{~F}-\mathrm{NMR} 282.4 \mathrm{MHz}\right)$, a Bruker Avance $400\left({ }^{1} \mathrm{H} \mathrm{NMR}\right.$ : $400 \mathrm{MHz} ;{ }^{13} \mathrm{C}$ NMR: $100 \mathrm{MHz} ;{ }^{31} \mathrm{P}$ NMR: $\left.162 \mathrm{MHz}\right)$ or a Bruker Avance $500\left({ }^{1} \mathrm{H}-\mathrm{NMR}\right.$ : 
$\left.500 \mathrm{MHz} ;{ }^{13} \mathrm{C}-\mathrm{NMR}, 125.8 \mathrm{MHz}\right) .{ }^{1} \mathrm{H}-\mathrm{NMR}$ experiments were performed in $\mathrm{CDCl}_{3}$ with $\mathrm{CHCl}_{3}(\delta=7.26 \mathrm{ppm})$ or $\mathrm{CD}_{3} \mathrm{OD}$ with $\mathrm{CD}_{2} \mathrm{HOD}(\delta=3.31 \mathrm{ppm})$ as internal references. ${ }^{13} \mathrm{C}$-NMR experiments were performed in $\mathrm{CDCl}_{3}$ with $\mathrm{CDCl}_{3}(\delta=77.23 \mathrm{ppm})$ or in $\mathrm{CD}_{3} \mathrm{OD}$ with $\mathrm{CD}_{2} \mathrm{HOD}(\delta=49.0 \mathrm{ppm})$ as internal references. For ${ }^{31} \mathrm{P}-\mathrm{NMR}$ and ${ }^{19} \mathrm{~F}-\mathrm{NMR}$ references, the spectrometer had external references, corresponding to $80 \%$ phosphoric acid in $\mathrm{D}_{2} \mathrm{O}$ ( $\delta=0 \mathrm{ppm})$ and to $0.05 \% \alpha, \alpha, \alpha$-trifluorotoluene in $\mathrm{CDCl}_{3}(\delta=-62.75 \mathrm{ppm})$. Chemical shifts are expressed in ppm and signal multiplicities are described using the following abbreviations: $\mathrm{s}$ for singlet, $\mathrm{d}$ for doublet, $\mathrm{t}$ for triplet, $\mathrm{q}$ for quartet, $\mathrm{p}$ for quintet and $\mathrm{m}$ for multiplet. In the presence of conformers, signals were differentiated by a ${ }^{*}$ sign added to the assignments. Negative or positive-mode electrospray MS were performed on a Bruker Daltonics microTOF spectrometer (Bruker Daltonik GmbH, Bremen, Germany) equipped with an orthogonal electrospray (ESI) interface. Calibration was performed using a solution of $10 \mathrm{mM}$ sodium formate. Sample solutions were introduced into the spectrometer source with a syringe pump (Harvard type 55 1111: Harvard Apparatus Inc., South Natick, MA, USA) with a flow rate of $5 \mu \mathrm{L} \mathrm{min}{ }^{-1}$.

\subsubsection{Synthesis of $\alpha, \alpha$-Difluorophosphonate Derivatives}

Synthesis of the intermediate diethyl 1,1-difluorobut-3-enylphosphonate (12) [31]. A solution of $\mathrm{BrZnCF}_{2} \mathrm{P}(\mathrm{O})(\mathrm{OEt})_{2}$ was prepared from diethyl (bromodifluoromethyl)phosphonate $(2.67 \mathrm{~g}, 10 \mathrm{mmol})$ and $\mathrm{Zn}$ dust $(0.65 \mathrm{~g}, 10 \mathrm{mmol})$ in DMF $(18 \mathrm{~mL})$. The reaction was stirred for $3 \mathrm{~h}$ at room temperature. $\mathrm{CuBr}(1.43 \mathrm{~g}, 10 \mathrm{mmol})$ was added, and the reaction mixture was stirred for $30 \mathrm{~min}$ before the addition of allyl bromide $(0.43 \mathrm{~mL}, 5 \mathrm{mmol})$. The reaction mixture was stirred overnight, quenched with a $10 \%$ aqueous solution of $\mathrm{HCl}$ $(10 \mathrm{~mL})$, filtered through celite and extracted with $\mathrm{Et}_{2} \mathrm{O}(3 \times 15 \mathrm{~mL})$. The organic layers were combined, washed with a saturated solution of $\mathrm{NaHCO}_{3}$ then with brine, dried over anhydrous $\mathrm{Na}_{2} \mathrm{SO}_{4}$ and evaporated to dryness. The product is obtained after purification by column chromatography (EtOAc/PE 3:7 to 1:1) as a colorless oil (1.02 g, 89\% yield). $R_{f}=0.54$ (EtOAc/PE 1:1); ${ }^{1} \mathrm{H}$ NMR (300 MHz, CDCl $): \delta=1.37(6 \mathrm{H}, \mathrm{t}, J=7.1 \mathrm{~Hz}), 2.73-2.93(2 \mathrm{H}, \mathrm{m})$, $4.26\left(4 \mathrm{H}, \mathrm{dq}, J_{\mathrm{HH}}=J_{\mathrm{PH}}=7.1 \mathrm{~Hz}\right), 5.22-5.31(2 \mathrm{H}, \mathrm{m}), 5.73-5.92(1 \mathrm{H}, \mathrm{m}) ;{ }^{13} \mathrm{C} \mathrm{NMR}(75.5 \mathrm{MHz}$, $\left.\mathrm{CDCl}_{3}\right): \delta=16.5\left(\mathrm{CH}_{3} \times 2, \mathrm{~d}, J_{\mathrm{CP}}=5.6 \mathrm{~Hz}\right), 38.8\left(\mathrm{CH}_{2}, \mathrm{dt}, J_{\mathrm{CF}}=21.5 \mathrm{~Hz}, J_{\mathrm{CP}}=15.1 \mathrm{~Hz}\right)$, $64.5\left(\mathrm{CH}_{2} \times 2, \mathrm{~d}, J_{\mathrm{CP}}=6.8 \mathrm{~Hz}\right), 119.7\left(\mathrm{CF}_{2}, \mathrm{dt}, J_{\mathrm{CF}}=260.0 \mathrm{~Hz}, J_{\mathrm{CP}}=215.1 \mathrm{~Hz}\right), 121.4\left(\mathrm{CH}_{2}\right)$, $127.1\left(\mathrm{CH}, \mathrm{dt}, J_{\mathrm{CF}}=11.4 \mathrm{~Hz}, J_{\mathrm{CP}}=5.6 \mathrm{~Hz}\right) ;{ }^{19} \mathrm{~F} \mathrm{NMR}\left(282 \mathrm{MHz}, \mathrm{CDCl}_{3}\right): \delta=-111.26(\mathrm{~d}$, $\left.J_{\mathrm{FP}}=107.5 \mathrm{~Hz}\right) ;{ }^{31} \mathrm{P}$ NMR $\left(121 \mathrm{MHz}, \mathrm{CDCl}_{3}\right): \delta=6.9\left(\mathrm{t}, J_{\mathrm{PF}}=107.5 \mathrm{~Hz}\right)$.

\subsubsection{Synthesis of the Target Compounds (9)}

Diethyl (1,1-difluoro-3-oxopropyl)phosphonate (13) [32]. Ozone was bubbled through a solution of diethyl 1,1-difluorobut-3-enylphosphonate 12 (2.28 g, $10 \mathrm{mmol})$ in DCM/MeOH $(50 \mathrm{~mL}, 4: 1)$ at $-78^{\circ} \mathrm{C}$ until the solution turned blue (5 min). Nitrogen was bubbled through the solution until the blue color disappeared (removal of excess ozone). Dimethylsulfide $(1.8 \mathrm{~mL}, 24.5 \mathrm{mmol})$ was added at $-78^{\circ} \mathrm{C}$ and the solution was allowed to warm up to room temperature. Solvents and excess of $\mathrm{Me}_{2} \mathrm{~S}$ were removed under reduced pressure, giving 13 as a colorless oil, which was immediately used without further purification for the next reaction. $R_{f}=0.46(\mathrm{PE} / \mathrm{EtOAc} 1: 1) ;{ }^{1} \mathrm{H} \mathrm{NMR}\left(300 \mathrm{MHz}, \mathrm{CDCl}_{3}\right): \delta=1.36(6 \mathrm{H}, \mathrm{td}$, $\left.J_{\mathrm{HH}}=7.1 \mathrm{~Hz}, J_{\mathrm{HP}}=0.6 \mathrm{~Hz}\right), 3.06\left(2 \mathrm{H}, \mathrm{tdd}, J_{\mathrm{HF}}=19.1 \mathrm{~Hz}, J_{\mathrm{HP}}=7.0 \mathrm{~Hz}, J_{\mathrm{HH}}=2.5 \mathrm{~Hz}\right), 4.27$ $\left(4 \mathrm{H}, \mathrm{dq}, J_{\mathrm{HP}}=8.2 \mathrm{~Hz}, J_{\mathrm{HH}}=7.1 \mathrm{~Hz}\right), 9.77(1 \mathrm{H}, \mathrm{t}, J=2.5 \mathrm{~Hz})$.

Diethyl (3-((benzyloxy)amino)-1,1-difluoropropyl)phosphonate (14) [21]. Diethyl (1,1-difluoro3-oxopropyl)phosphonate $\mathbf{1 3}(2.3 \mathrm{~g}, 10 \mathrm{mmol})$ and $\mathrm{N}$-hydroxybenzylamine hydrochloride $(1.6 \mathrm{~g}, 10 \mathrm{mmol})$ in $8 \mathrm{~mL} \mathrm{MeOH}$ were stirred for $1 \mathrm{~h}$ at room temperature. The solution was diluted with more $\mathrm{MeOH}(142 \mathrm{~mL})$, and sodium cyanoborohydride $(1.89 \mathrm{~g}, 30 \mathrm{mmol})$ was added portion wise over $30 \mathrm{~min}$. The reaction mixture was cooled to $0{ }^{\circ} \mathrm{C}$ before the dropwise addition of $\mathrm{HCl} 37 \%$ in water $(10 \mathrm{~mL}, 100 \mathrm{mmol})$ over $40 \mathrm{~min}$. Sodium cyanoborohydride $(0.44 \mathrm{~g})$ was then added at room temperature and the mixture left to stir for $2 \mathrm{~h}$. The solution was evaporated and treated with aqueous $\mathrm{KOH}(10 \%)$ to obtain a basic $\mathrm{pH}$. The product was extracted with EtOAc $(3 \times 70 \mathrm{~mL})$, and the combined organic layers 
were dried over $\mathrm{Na}_{2} \mathrm{SO}_{4}$ and evaporated to dryness under reduced pressure. 14 (1.19 g, $35 \%$ yield) was obtained as a transparent oil after purification by chromatography column on silica gel with PE/EtOAc (100:0 to 50:50) as eluent. $\mathrm{R}_{\mathrm{f}}=0.54$ (EtOAc/PE 7:3); ${ }^{1} \mathrm{H}$ NMR $\left(500 \mathrm{MHz}, \mathrm{CDCl}_{3}\right): \delta=1.37(6 \mathrm{H}, \mathrm{t}, J=7.1 \mathrm{~Hz}), 2.36\left(2 \mathrm{H}, \mathrm{tq}, J_{\mathrm{HF}}=20.2 \mathrm{~Hz}, J_{\mathrm{HH}}=J_{\mathrm{HP}}=6.6 \mathrm{~Hz}\right)$, $3.18-3.25(2 \mathrm{H}, \mathrm{t}, J=7.1 \mathrm{~Hz}), 4.22-4.31(4 \mathrm{H}, \mathrm{m}), 4.70(2 \mathrm{H}, \mathrm{s}), 5.76(1 \mathrm{H}, \mathrm{br} \mathrm{s}), 7.27-7.39(5 \mathrm{H}$, m); ${ }^{13} \mathrm{C} \mathrm{NMR}\left(125 \mathrm{MHz}, \mathrm{CDCl}_{3}\right): \delta=16.4\left(\mathrm{CH}_{3} \times 2, \mathrm{~d}, J_{\mathrm{CP}}=5.1 \mathrm{~Hz}\right), 32.2\left(\mathrm{CH}_{2} \mathrm{CF}_{2}, \mathrm{td}\right.$, $\left.J_{\mathrm{CF}}=20.4 \mathrm{~Hz}, J_{\mathrm{CP}}=14.4 \mathrm{~Hz}\right), 44.4\left(\mathrm{CH}_{2} \mathrm{~N}, \mathrm{q}, J_{\mathrm{CF}}=5.1 \mathrm{~Hz}\right), 64.6\left(\mathrm{CH}_{2} \times 2, \mathrm{~d}, J_{\mathrm{CP}}=6.7 \mathrm{~Hz}\right)$, $76.2\left(\mathrm{CH}_{2} \mathrm{Ph}\right), 120.5\left(\mathrm{CF}_{2}, \mathrm{td}, J_{\mathrm{CF}}=257.8 \mathrm{~Hz}, J_{\mathrm{CP}}=214.7 \mathrm{~Hz}\right), 127.9\left(\mathrm{CH}_{\mathrm{ar}}\right), 128.4\left(\mathrm{CH}_{\mathrm{ar}} \times 2\right)$, $128.4\left(\mathrm{CH}_{\mathrm{ar}} \times 2\right), 137.7\left(\mathrm{C}_{\mathrm{ar}}\right) ;{ }^{19} \mathrm{~F} \mathrm{NMR}\left(282 \mathrm{MHz}, \mathrm{CDCl}_{3}\right): \delta=-111.08\left(\mathrm{~d}, \mathrm{~J}_{\mathrm{FP}}=107.9 \mathrm{~Hz}\right)$; ${ }^{31} \mathrm{P}$ NMR $\left(121 \mathrm{MHz}, \mathrm{CDCl}_{3}\right): \delta=7.00\left(\mathrm{t}, J_{\mathrm{PF}}=107.3 \mathrm{~Hz}\right)$.

Diethyl (3-(N-(benzyloxy)formamido)-1,1-difluoropropyl)phosphonate (15a). Formic acid $(2.8 \mathrm{~mL}, 74.1 \mathrm{mmol})$ and acetic anhydride $(1.4 \mathrm{~mL}, 14.8 \mathrm{mmol})$ were stirred for $30 \mathrm{~min}$ at room temperature. The solution was cooled to $0{ }^{\circ} \mathrm{C}$ then diethyl (3-((benzyloxy)amino)-1,1difluoropropyl)phosphonate $\mathbf{1 4}(500 \mathrm{mg}, 1.5 \mathrm{mmol})$ dissolved in anhydrous THF (1.5 mL) was added dropwise. The reaction mixture was stirred for $10 \mathrm{~min}$ at $0{ }^{\circ} \mathrm{C}$ and overnight at room temperature. EtOAc $(15 \mathrm{~mL})$ was added and the resulting organic layer washed with water $(2 \times 10 \mathrm{~mL})$ and aqueous $\mathrm{KOH}(0.1 \mathrm{M}, 10 \mathrm{~mL})$, dried over $\mathrm{Na}_{2} \mathrm{SO}_{4}$ and evaporated to dryness under reduced pressure. A purification by flash chromatography on silica gel with EtOAc/PE 7:3 as eluent gave 15a as a light yellow oil (450 $\mathrm{mg}, 83 \%$ yield) and as a mixture of two conformers in a 2:8 ratio, respectively. $\mathrm{R}_{\mathrm{f}}=0.54$ (EtOAc/PE 7:3); ${ }^{1} \mathrm{H}$ NMR $\left(300 \mathrm{MHz}, \mathrm{CDCl}_{3}\right): \delta=1.37(6 \mathrm{H}, \mathrm{t}, J=7.2 \mathrm{~Hz}), 2.29-2.52(2 \mathrm{H}, \mathrm{m}), 3.48-3.70(2 / 10 \mathrm{of} 2 \mathrm{H}$, s), 3.76-3.94 (8/10 of $2 \mathrm{H}, \mathrm{s}), 4.20-4.33(4 \mathrm{H}, \mathrm{m}), 4.86(2 \mathrm{H}, \mathrm{s}), 7.27-7.39(5 \mathrm{H}, \mathrm{m}), 8.16(1 \mathrm{H}, \mathrm{s})$; ${ }^{13} \mathrm{C} \mathrm{NMR}\left(125 \mathrm{MHz}, \mathrm{CDCl}_{3}\right): \delta=16.4\left(\mathrm{CH}_{3} \times 2, \mathrm{~d}, \mathrm{~J}_{\mathrm{CP}}=5.4 \mathrm{~Hz}\right), 30.6-31.4\left(\mathrm{CH}_{2} \mathrm{CF}_{2}, \mathrm{~m}\right)$, $37.2\left(\mathrm{CH}_{2} \mathrm{~N}\right), 41.8\left(\mathrm{CH}_{2} \mathrm{~N}^{*}\right), 64.72\left(\mathrm{CH}_{2} \times 2, \mathrm{~d}, J_{\mathrm{CP}}=6.7 \mathrm{~Hz}\right), 77.8\left(\mathrm{CH}_{2} \mathrm{Ph}\right), 119.6\left(\mathrm{CF}_{2}, \mathrm{td}\right.$, $\left.J_{\mathrm{CF}}=258.6 \mathrm{~Hz}, J_{\mathrm{CP}}=215.1 \mathrm{~Hz}\right), 128.8\left(\mathrm{CH}_{\mathrm{ar}}\right), 129.2\left(\mathrm{CH}_{\mathrm{ar}}{ }^{*}\right), 129.5\left(\mathrm{CH}_{\mathrm{ar}}\right), 134.1\left(\mathrm{C}_{\mathrm{ar}}\right), 134.6$ $\left(\mathrm{C}_{\mathrm{ar}}{ }^{*}\right), 158.2\left(\mathrm{CO}^{*}\right), 163.3(\mathrm{CO}) ;{ }^{19} \mathrm{~F} \mathrm{NMR}\left(282 \mathrm{MHz}, \mathrm{CDCl}_{3}\right): \delta=-113.0\left(\mathrm{~d}, \mathrm{~J}_{\mathrm{FP}}=121.2 \mathrm{~Hz}\right)$, $-113.4\left(\mathrm{~d}, J_{\mathrm{FP}}=106.2 \mathrm{~Hz}\right) ;{ }^{31} \mathrm{P}$ NMR $\left(121 \mathrm{MHz}, \mathrm{CDCl}_{3}\right): \delta=6.38\left(\mathrm{t}, J_{\mathrm{PF}}=105.8 \mathrm{~Hz}\right)$; HRMS $\left(\mathrm{ESI}^{+}\right) \mathrm{m} / \mathrm{z}$ calcd for $\mathrm{C}_{15} \mathrm{H}_{22} \mathrm{~F}_{2} \mathrm{NNaO}_{5} \mathrm{P}[\mathrm{M}+\mathrm{Na}]^{+} 388.1096$, found 388.1099.

Diethyl (3-(N-(benzyloxy)acetamido)-1,1-difluoropropyl)phosphonate (15b) [21]. Anhydrous pyridine $(0.4 \mathrm{~mL}, 4.4 \mathrm{mmol})$ was added dropwise to a solution of diethyl (3-((benzyloxy) amino)-1,1-difluoropropyl)phosphonate $14(500 \mathrm{mg}, 1.5 \mathrm{mmol})$ in acetic anhydride $(6 \mathrm{~mL}$, $63.5 \mathrm{mmol})$. The reaction mixture was stirred overnight at room temperature then evaporated to dryness under reduced pressure. A purification by flash chromatography on silica gel with EtOAc/PE 7:3 as eluent gave 15b as a transparent oil $(450 \mathrm{mg}, 80 \%$ yield) and as a single conformer. $\mathrm{R}_{\mathrm{f}}=0.55\left(\mathrm{EtOAc} / \mathrm{PE} \mathrm{7:3);}{ }^{1} \mathrm{H}\right.$ NMR $\left(300 \mathrm{MHz}, \mathrm{CDCl}_{3}\right)$ : $\delta=1.37(6 \mathrm{H}, \mathrm{t}, J=7.6 \mathrm{H}), 2.07(3 \mathrm{H}, \mathrm{s}), 2.29-2.53(2 \mathrm{H}, \mathrm{m}), 3.87-3.95(2 \mathrm{H}, \mathrm{m}), 4.26(4 \mathrm{H}$, pseudo p, $\left.J_{\mathrm{HH}}=J_{\mathrm{HP}}=7.2 \mathrm{~Hz}\right), 4.83(2 \mathrm{H}, \mathrm{s}), 7.30-7.43(5 \mathrm{H}, \mathrm{m}) ;{ }^{13} \mathrm{C} \mathrm{NMR}(125 \mathrm{MHz}$, $\left.\mathrm{CDCl}_{3}\right): \delta=16.4\left(\mathrm{CH}_{3} \times 2, \mathrm{~d}, \mathrm{~J}_{\mathrm{CP}}=5.4 \mathrm{~Hz}\right), 20.6\left(\mathrm{CH}_{3} \mathrm{CO}\right), 30.5-31.1\left(\mathrm{CH}_{2} \mathrm{CF}_{2}, \mathrm{~m}\right), 38.5$ $\left(\mathrm{CH}_{2} \mathrm{~N}\right), 64.7\left(\mathrm{CH}_{2} \times 2, \mathrm{~d}, \mathrm{~J}_{\mathrm{CP}}=6.8 \mathrm{~Hz}\right), 76.5\left(\mathrm{OCH}_{2} \mathrm{Ph}\right), 119.8\left(\mathrm{CF}_{2}, \mathrm{td}, J_{\mathrm{CF}}=259.9 \mathrm{~Hz}\right.$, $\left.J_{\mathrm{CP}}=216.3 \mathrm{~Hz}\right), 128.8\left(\mathrm{CH}_{\mathrm{ar}} \times 2\right), 129.1\left(\mathrm{CH}_{\mathrm{ar}}\right), 129.3\left(\mathrm{CH}_{\mathrm{ar}} \times 2\right), 134.2\left(\mathrm{C}_{\mathrm{ar}}\right), 172.9(\mathrm{CO})$; ${ }^{19} \mathrm{~F} \mathrm{NMR}\left(282 \mathrm{MHz}, \mathrm{CDCl}_{3}\right): \delta=-112.33\left(\mathrm{~d}, J_{\mathrm{FP}}=106.7 \mathrm{~Hz}\right) ;{ }^{31} \mathrm{P}$ NMR $\left(121 \mathrm{MHz}, \mathrm{CDCl}_{3}\right)$ : $\delta=6.38\left(\mathrm{t}, J_{\mathrm{PF}}=106.7 \mathrm{~Hz}\right)$.

Diethyl (1,1-difluoro-3-(N-hydroxyformamido)propyl)phosphonate (16a). Diethyl (3-(N(benzyloxy)formamido)-1,1-difluoropropyl)phosphonate 15a (438 mg, $1.2 \mathrm{mmol}$ ) and palladium on charcoal $(45 \mathrm{mg}, 10 \%)$ were introduced in a 2-neck-flask with a three-way tap under a nitrogen atmosphere. After the addition of HPLC grade $\mathrm{MeOH}(30 \mathrm{~mL})$, the reaction mixture was degassed three times then left to stir for $24 \mathrm{~h}$ under hydrogen at atmospheric pressure. The solution was filtered over celite and evaporated to dryness under reduced pressure. A purification by chromatography column with EtOAc as eluent gave 16a as an orange oil ( $245 \mathrm{mg}, 74 \%$ yield) and as a mixture of two conformers in a 1:1 ratio. $\mathrm{R}_{\mathrm{f}}=0.39$ (EtOAc); ${ }^{1} \mathrm{H} \mathrm{NMR}\left(500 \mathrm{MHz}, \mathrm{CDCl}_{3}\right): \delta=1.38(6 \mathrm{H}, \mathrm{t}, J=7.1 \mathrm{~Hz}), 2.37-2.58$ $(2 \mathrm{H}, \mathrm{m}), 3.80-3.88(2 \mathrm{H}, \mathrm{m}), 4.28\left(4 \mathrm{H}\right.$, pseudo $\left.\mathrm{p}, J_{\mathrm{HH}}=J_{\mathrm{HP}}=7.4 \mathrm{~Hz}\right), 7.91(1 / 2 \mathrm{of} 1 \mathrm{H}, \mathrm{s})$, $8.35(1 / 2$ of $1 \mathrm{H}, \mathrm{s}) ;{ }^{13} \mathrm{C}$ NMR $\left(125 \mathrm{MHz}, \mathrm{CDCl}_{3}\right): \delta=16.3\left(\mathrm{CH}_{3} \times 2, \mathrm{~d}, J_{\mathrm{CP}}=5.4 \mathrm{~Hz}\right), 16.4$ $\left(\mathrm{CH}_{3} \times 2, \mathrm{~d}, J=5.4 \mathrm{~Hz}\right), 31.6\left(\mathrm{CH}_{2} \mathrm{CF}_{2}, \mathrm{dt}, J_{\mathrm{CF}}=20.7 \mathrm{~Hz}, J_{\mathrm{CP}}=14.4 \mathrm{~Hz}\right), 32.7\left(\mathrm{CH}_{2} \mathrm{CF}_{2}{ }^{*}, \mathrm{dt}\right.$, 
$\left.J_{\mathrm{CF}}=20.7 \mathrm{~Hz}, J_{\mathrm{CP}}=14.4 \mathrm{~Hz}\right), 41.6\left(\mathrm{CH}_{2} \mathrm{~N}, \mathrm{q}, J_{\mathrm{CF}}=6.1 \mathrm{~Hz}\right), 42.5\left(\mathrm{CH}_{2} \mathrm{~N}^{*}, \mathrm{q}, J_{\mathrm{CF}}=6.1 \mathrm{~Hz}\right), 65.0$ $\left(\mathrm{CH}_{2} \mathrm{O} \times 2, \mathrm{~d}, J_{\mathrm{CP}}=7.0 \mathrm{~Hz}\right), 65.6\left(\mathrm{CH}_{2} \mathrm{O}^{*} \times 2, \mathrm{~d}, J_{\mathrm{CP}}=7.0 \mathrm{~Hz}\right), 119.6\left(\mathrm{CF}_{2}, \mathrm{td}, J_{\mathrm{CF}}=259.3 \mathrm{~Hz}\right.$, $\left.J_{\mathrm{CP}}=211.7 \mathrm{~Hz}\right), 119.9\left(\mathrm{CF}_{2}{ }^{*}, \mathrm{td}, J_{\mathrm{CF}}=259.3 \mathrm{~Hz}, J_{\mathrm{CP}}=211.7 \mathrm{~Hz}\right), 156.3\left(\mathrm{CO}^{*}\right), 163.1(\mathrm{CO})$; ${ }^{19} \mathrm{~F}$ NMR $\left(282 \mathrm{MHz}, \mathrm{CDCl}_{3}\right): \delta=-112.70\left(\mathrm{~d}, \mathrm{~J}_{\mathrm{FP}}=105.0 \mathrm{~Hz}\right),-109.12\left(\mathrm{~d}, J_{\mathrm{FP}}=107.7 \mathrm{~Hz}\right)$; ${ }^{31} \mathrm{P}$ NMR $\left(121 \mathrm{MHz}, \mathrm{CDCl}_{3}\right) \delta 6.14\left(\mathrm{t}, J_{\mathrm{PF}}=104.7 \mathrm{~Hz}\right), 7.39\left(\mathrm{t}, J_{\mathrm{PF}}=107.4 \mathrm{~Hz}\right) ; \mathrm{HRMS}_{\left(\mathrm{ESI}^{+}\right)}$ $\mathrm{m} / z$ calcd for $\mathrm{C}_{8} \mathrm{H}_{16} \mathrm{~F}_{2} \mathrm{NNaO}_{5} \mathrm{P}[\mathrm{M}+\mathrm{Na}]^{+} 298.0626$, found 298.0625 .

Diethyl (1,1-difluoro-3-(N-hydroxyacetamido)propyl)phosphonate (16b) [21]. Diethyl (3( $N$-(benzyloxy)acetamido)-1,1-difluoropropyl)phosphonate $15 \mathbf{b}(450 \mathrm{mg}, 1.2 \mathrm{mmol})$ and palladium on charcoal $(45 \mathrm{mg}, 10 \%)$ were introduced in a 2-neck-flask with a three-way tap under a nitrogen atmosphere. After the addition of HPLC grade $\mathrm{MeOH}(30 \mathrm{~mL})$, the reaction mixture was degassed three times then left to stir for $24 \mathrm{~h}$ under a hydrogen atmosphere. The solution was filtered over a pad of celite and evaporated to dryness under reduced pressure. A purification by chromatography column with EtOAc as eluent gave $16 \mathbf{b}$ as a light yellow oil ( $280 \mathrm{mg}, 80 \%$ yield) and as a mixture of two conformers in a 2:8 ratio respectively. $\mathrm{R}_{\mathrm{f}}=0.41(\mathrm{EtOAc}) ;{ }^{1} \mathrm{H} \mathrm{NMR}\left(500 \mathrm{MHz}, \mathrm{CDCl}_{3}\right): \delta=1.38(6 \mathrm{H}, \mathrm{t}$, $J=7.1 \mathrm{~Hz}), 2.13(3 \mathrm{H}, \mathrm{s}), 2.37-2.55(2 \mathrm{H}, \mathrm{m}), 3.82-3.90(8 / 10$ of $2 \mathrm{H}, \mathrm{t}, J=5.9 \mathrm{~Hz}), 3.91-3.99$ $(2 / 10$ of $2 \mathrm{H}, \mathrm{m}), 4.27\left(4 \mathrm{H}\right.$, pseudo $\left.\mathrm{p}, J_{\mathrm{HH}}=J_{\mathrm{HP}}=6.8 \mathrm{~Hz}\right) ;{ }^{13} \mathrm{C} \mathrm{NMR}\left(125 \mathrm{MHz}, \mathrm{CDCl}_{3}\right)$ : $\delta=16.3\left(\mathrm{CH}_{3} \times 2, \mathrm{~d}, J_{\mathrm{CP}}=5.5 \mathrm{~Hz}\right), 18.3\left(\mathrm{CH}_{3} \mathrm{CO}^{*}\right), 20.4\left(\mathrm{CH}_{3} \mathrm{CO}\right), 31.2-31.7\left(\mathrm{CH}_{2} \mathrm{CF}_{2}{ }^{*}, \mathrm{~m}\right)$, $33.3\left(\mathrm{CH}_{2} \mathrm{CF}_{2}, \mathrm{dt}, J_{\mathrm{CF}}=22.0 \mathrm{~Hz}, J_{\mathrm{CP}}=14.7 \mathrm{~Hz}\right), 41.9-42.2\left(\mathrm{CH}_{2} \mathrm{~N}^{*}, \mathrm{~m}\right), 43.3-43.6\left(\mathrm{CH}_{2} \mathrm{~N}, \mathrm{~m}\right)$, 64.7-65.0 $\left(\mathrm{CH}_{2} \mathrm{O}^{*} \times 2, \mathrm{~m}\right), 65.50\left(\mathrm{CH}_{2} \mathrm{O} \times 2, \mathrm{~d}, J_{\mathrm{CP}}=7.3 \mathrm{~Hz}\right), 120.2\left(\mathrm{CF}_{2}, \mathrm{td}, J_{\mathrm{CF}}=258.7 \mathrm{~Hz}\right.$, $\left.J_{\mathrm{CP}}=210.7 \mathrm{~Hz}\right), 164.8\left(\mathrm{CO}^{*}\right), 172.6(\mathrm{CO}) ;{ }^{19} \mathrm{~F} \mathrm{NMR}\left(282 \mathrm{MHz}, \mathrm{CDCl}_{3}\right): \delta=-113.49(\mathrm{~d}$, $\left.\mathrm{J}_{\mathrm{FP}}=105.1 \mathrm{~Hz}\right),-108.2\left(\mathrm{~d}, J_{\mathrm{FP}}=108.5 \mathrm{~Hz}\right) ;{ }^{31} \mathrm{P} \mathrm{NMR}\left(121 \mathrm{MHz}, \mathrm{CDCl}_{3}\right): \delta=6.17(\mathrm{t}$, $\left.J_{\mathrm{PF}}=106.1 \mathrm{~Hz}\right), 7.57\left(\mathrm{t}, J_{\mathrm{PF}}=108.1 \mathrm{~Hz}\right)$.

(1,1-Difluoro-3-(N-hydroxyacetamido)propyl)phosphonic acid (9b). A solution of diethyl (1,1-difluoro-3-(N-hydroxyacetamido)propyl)phosphonate 16b (25 mg, $86 \mu \mathrm{mol})$ dissolved in DCM $(0.32 \mathrm{~mL})$ was cooled to $0{ }^{\circ} \mathrm{C}$. TMSBr $(0.11 \mathrm{~mL}, 0.9 \mathrm{mmol})$ was added dropwise at $0{ }^{\circ} \mathrm{C}$ then the reaction mixture was stirred overnight in the dark at room temperature. DCM and excess of TMSBr were evaporated under reduced pressure and the intermediate orange oil was treated with water $(0.5 \mathrm{~mL}, 27.8 \mathrm{mmol})$ for $1.5 \mathrm{~h}$. Removal of water under vacuum afforded $9 \mathbf{b}$ as an orange oil ( $20 \mathrm{mg}$, quant. yield) and as a mixture of conformers. $R_{f}=0.14(\mathrm{EtOAc}) ;{ }^{1} \mathrm{H}$ NMR $\left(400 \mathrm{MHz}, \mathrm{CD}_{3} \mathrm{OD}\right): \delta=2.02(5 / 10$ of $3 \mathrm{H}, \mathrm{s}), 2.10(5 / 10 \mathrm{of} 3 \mathrm{H}$, s), $2.34-2.46(4 / 10$ of $2 \mathrm{H}, \mathrm{m}), 2.52-2.64(6 / 10$ of $2 \mathrm{H}, \mathrm{m}), 3.53(5 / 10$ of $2 \mathrm{H}, \mathrm{t}, J=7.6 \mathrm{~Hz})$, $3.89(4 / 10$ of $2 \mathrm{H}, \mathrm{t}, J=7.6 \mathrm{~Hz}), 4.10-4.26(1 / 10$ of $2 \mathrm{H}, \mathrm{m}) ;{ }^{13} \mathrm{C}$ NMR $\left(125 \mathrm{MHz}, \mathrm{CD}_{3} \mathrm{OD}\right)$ : $\delta=20.2\left(\mathrm{CH}_{3} \mathrm{CO}^{*}\right), 20.6\left(\mathrm{CH}_{3} \mathrm{CO}\right), 29.6\left(\mathrm{CH}_{2} \mathrm{CF}_{2}, \mathrm{td}, J_{\mathrm{CF}}=22.3 \mathrm{~Hz}, J_{\mathrm{CP}}=15.7 \mathrm{~Hz}\right), 32.0$ $\left(\mathrm{CH}_{2} \mathrm{CF}_{2}{ }^{*}, \mathrm{td}, J_{\mathrm{CF}}=20.2 \mathrm{~Hz}, J_{\mathrm{CP}}=14.5 \mathrm{~Hz}\right), 42.2-42.5\left(\mathrm{CH}_{2} \mathrm{~N}^{*}, \mathrm{~m}\right), 45.6-45.8\left(\mathrm{CH}_{2} \mathrm{~N}, \mathrm{~m}\right)$, $120.6\left(\mathrm{CF}_{2}, \mathrm{td}, J_{\mathrm{CF}}=258.9 \mathrm{~Hz}, J_{\mathrm{CP}}=210.2 \mathrm{~Hz}\right), 173.4(\mathrm{CO}), 173.9\left(\mathrm{CO}^{*}\right) ;{ }^{19} \mathrm{~F}$ NMR $(282 \mathrm{MHz}$, $\left.\mathrm{CD}_{3} \mathrm{OD}\right): \delta=-115.5\left(\mathrm{~d}, J_{\mathrm{FP}}=100.3 \mathrm{~Hz}\right),-115.7\left(\mathrm{~d}, J_{\mathrm{FP}}=99.4 \mathrm{~Hz}\right),-116.3\left(\mathrm{~d}, J_{\mathrm{FP}}=103.7 \mathrm{~Hz}\right)$; ${ }^{31} \mathrm{P}$ NMR $\left(162 \mathrm{MHz}, \mathrm{CD}_{3} \mathrm{OD}\right): \delta=5.00\left(\mathrm{t}, J_{\mathrm{PF}}=103.8 \mathrm{~Hz}\right), 3.96\left(\mathrm{t}, J_{\mathrm{PF}}=100.1 \mathrm{~Hz}\right), 3.78$ $\left(\mathrm{t}, J_{\mathrm{PF}}=99.6 \mathrm{~Hz}\right) ; \mathrm{HRMS}\left(\mathrm{ESI}^{-}\right) \mathrm{m} / z$ calcd for $\mathrm{C}_{5} \mathrm{H}_{10} \mathrm{~F}_{2} \mathrm{NO}_{5} \mathrm{P}[\mathrm{M}-\mathrm{H}]^{-} 232.0192$, found 232.0181.

\subsubsection{Synthesis of the Target Compounds (10)}

Diethyl 1,1-difluorobutan-4-ol phosphonate (17). A $1 \mathrm{M}$ solution of borane in THF (32 mL, $32 \mathrm{mmol}$ ) was added dropwise to a stirred solution of diethyl 1,1-difluorobut3-enylphosphonate $12(1.84 \mathrm{~g}, 8 \mathrm{mmol})$ in THF $(20 \mathrm{~mL})$ at $0{ }^{\circ} \mathrm{C}$. After $30 \mathrm{~min}$, the reaction mixture was allowed to warm up at room temperature for $4 \mathrm{~h}$. More borane solution $(16 \mathrm{~mL})$ was added dropwise at $0{ }^{\circ} \mathrm{C}$ and the mixture was stirred overnight at room temperature. Then, methanol $(10 \mathrm{~mL})$, a $3 \mathrm{M}$ solution of $\mathrm{NaOH}$ in water $(4 \mathrm{~mL})$ and a $30 \%$ aqueous solution of $\mathrm{H}_{2} \mathrm{O}_{2}(4 \mathrm{~mL})$ were successively added. The mixture was heated at $50{ }^{\circ} \mathrm{C}$ for $1 \mathrm{~h}$, quenched with brine $(30 \mathrm{~mL})$ and extracted with chloroform $(3 \times 20 \mathrm{~mL})$. The organic layers were combined, dried over anhydrous $\mathrm{Na}_{2} \mathrm{SO}_{4}$ and evaporated to dryness. Purification by column chromatography (PE/EtOAc 3:2 to 100\% EtOAc) yielded $\mathbf{1 7}$ as a colorless oil (770 mg, 39\% yield). $\mathrm{R}_{\mathrm{f}}=0.29$ (EtOAc/PE 7:3); ${ }^{1} \mathrm{H} \mathrm{NMR}\left(300 \mathrm{MHz}, \mathrm{CDCl}_{3}\right): \delta=1.37(6 \mathrm{H}, \mathrm{td}$, $\left.J_{\mathrm{HH}}=7.1 \mathrm{~Hz}, J_{\mathrm{PH}}=0.6 \mathrm{~Hz}\right), 1.62(1 \mathrm{H}, \mathrm{br} \mathrm{s}, \mathrm{OH}), 1.78-1.87(2 \mathrm{H}, \mathrm{m}), 2.06-2.26(2 \mathrm{H}, \mathrm{m}), 3.67$ 
$(2 \mathrm{H}, \mathrm{t}, J=6.2 \mathrm{~Hz}), 4.26\left(4 \mathrm{H}, \mathrm{dq}, J_{\mathrm{PH}}=7.9 \mathrm{~Hz}, J_{\mathrm{HH}}=7.1 \mathrm{~Hz}\right) ;{ }^{13} \mathrm{C} \mathrm{NMR}\left(125 \mathrm{MHz}, \mathrm{CDCl}_{3}\right)$ : $\delta=16.4\left(\mathrm{CH}_{3}, \mathrm{~d}, J_{\mathrm{CP}}=5.5 \mathrm{~Hz}\right), 24.0\left(\mathrm{CH}_{2}, \mathrm{dt}, J_{\mathrm{CF}}=4.9 \mathrm{~Hz}, J_{\mathrm{CP}}=4.4 \mathrm{~Hz}\right), 30.5\left(\mathrm{CH}_{2}, \mathrm{td}\right.$, $\left.J_{\mathrm{CF}}=21.1 \mathrm{~Hz}, J_{\mathrm{CP}}=14.9 \mathrm{~Hz}\right), 61.9\left(\mathrm{CH}_{2} \mathrm{OH}\right), 64.5\left(\mathrm{CH}_{2} \times 2, \mathrm{~d}, J_{\mathrm{CP}}=6.8 \mathrm{~Hz}\right), 121.0\left(\mathrm{CF}_{2}, \mathrm{td}\right.$, $\left.J_{\mathrm{CF}}=259.3 \mathrm{~Hz}, J_{\mathrm{CP}}=215.7 \mathrm{~Hz}\right) ;{ }^{19} \mathrm{~F} \mathrm{NMR}\left(282 \mathrm{MHz}, \mathrm{CDCl}_{3}\right): \delta=112.7\left(\mathrm{~d}, J_{\mathrm{FP}}=109.3 \mathrm{~Hz}\right)$; ${ }^{31} \mathrm{P}$ NMR $\left(121 \mathrm{MHz}, \mathrm{CDCl}_{3}\right): \delta=7.49\left(\mathrm{t}, J_{\mathrm{PF}}=109.3 \mathrm{~Hz}\right)$.

Difluoro-4-(diethyl phosphonate) butanoic acid (18) [21]. To a stirred solution of $\mathbf{1 7}(400 \mathrm{mg}$, $1.6 \mathrm{mmol})$ in $\mathrm{MeCN}(4 \mathrm{~mL})$ were successively added TEMPO $(51 \mathrm{mg}, 0.3 \mathrm{mmol})$, BAIB $(1.151 \mathrm{~g}, 3.6 \mathrm{mmol})$ and water $(4 \mathrm{~mL})$. The reaction mixture was stirred overnight then concentrated under reduced pressure. An aqueous saturated solution of $\mathrm{NaHCO}_{3}$ was added to reach a $\mathrm{pH}>8$. The solution was extracted with $\mathrm{DCM}(3 \times 15 \mathrm{~mL})$ to remove excess of starting materials. A $10 \% \mathrm{HCl}$ solution was added to the aqueous layer until $\mathrm{pH}<5$. Then the solution was extracted with DCM $(3 \times 15 \mathrm{~mL})$, the organic layer was dried over anhydrous $\mathrm{Na}_{2} \mathrm{SO}_{4}$ and evaporated to dryness. The product was not further purified and obtained as a light yellow oil (420 mg, 99\% yield). $\mathrm{R}_{\mathrm{f}}=0.26$ (EtOAc/PE 7:3); ${ }^{1} \mathrm{H}$ NMR $\left(500 \mathrm{MHz}, \mathrm{CDCl}_{3}\right): \delta=1.38(6 \mathrm{H}, \mathrm{t}, J=7.1 \mathrm{~Hz}), 2.35-2.51(2 \mathrm{H}, \mathrm{m}), 2.63-2.70(2 \mathrm{H}$, m), 4.28-4.31 $\left(4 \mathrm{H}\right.$, pseudo $\left.\mathrm{p}, J_{\mathrm{HH}}=J_{\mathrm{PH}}=7.2 \mathrm{~Hz}\right), 9.61(1 \mathrm{H}$, br s$) ;{ }^{13} \mathrm{C} \mathrm{NMR}(125 \mathrm{MHz}$, $\left.\mathrm{CDCl}_{3}\right): \delta=16.5\left(\mathrm{CH}_{3} \times 2, \mathrm{~d}, J_{\mathrm{CP}}=5.5 \mathrm{~Hz}\right), 25.8\left(\mathrm{CH}_{2} \mathrm{CF}_{2}, \mathrm{q}, J_{\mathrm{CP}}=5.4 \mathrm{~Hz}\right), 29.1\left(\mathrm{CH}_{2} \mathrm{CO}, \mathrm{dt}\right.$, $\left.J_{\mathrm{CF}}=21.2 \mathrm{~Hz}, J_{\mathrm{CP}}=15.9 \mathrm{~Hz}\right), 64.8\left(\mathrm{CH}_{2} \times 2, \mathrm{~d}, J_{\mathrm{CP}}=6.9 \mathrm{~Hz}\right), 119.8\left(\mathrm{CF}_{2}, \mathrm{dt}, J_{\mathrm{CF}}=259.8 \mathrm{~Hz}\right.$, $\left.J_{\mathrm{CP}}=217.2 \mathrm{~Hz}\right), 176.5(\mathrm{CO}) ;{ }^{19} \mathrm{~F} \mathrm{NMR}\left(282 \mathrm{MHz}, \mathrm{CDCl}_{3}\right): \delta=-112.75\left(\mathrm{~d}, J_{\mathrm{FP}}=107.6 \mathrm{~Hz}\right)$; ${ }^{31} \mathrm{P}$ NMR $\left(121 \mathrm{MHz}, \mathrm{CDCl}_{3}\right): \delta=6.48\left(\mathrm{t}, J_{\mathrm{PF}}=107.5 \mathrm{~Hz}\right.$.

Diethyl 4-(N-benzyloxy)-amino-1,1-difluoro-4-oxobutyl phosphonate (19a) [21]. CDI (0.528 g, $3.2 \mathrm{mmol})$ and $\mathrm{BnONH}_{2} \cdot \mathrm{HCl}(0.567 \mathrm{~g}, 3.5 \mathrm{mmol})$ were added to a solution of 4,4-difluoro-4(diethylphosphonate)butanoic acid $18(0.770 \mathrm{~g}, 2.9 \mathrm{mmol})$ in DCM $(60 \mathrm{~mL})$. The mixture was stirred overnight at room temperature. The reaction was quenched with a saturated aqueous solution of $\mathrm{NH}_{4} \mathrm{Cl}(60 \mathrm{~mL})$, and the resulting mixture was extracted with DCM $(3 \times 20 \mathrm{~mL})$. The organic layers were combined, washed with brine $(60 \mathrm{~mL})$, dried over anhydrous $\mathrm{Na}_{2} \mathrm{SO}_{4}$ and evaporated to dryness under reduced pressure. The product was purified by flash chromatography (EtOAc/PE 7:3) and obtained as a colorless oil (995 mg, $92 \%$ yield) as a mixture of two conformers in a 7:3 ratio respectively. $\mathrm{R}_{\mathrm{f}}=0.35$ (EtOAc $/ \mathrm{PE}$ 7:3); ${ }^{1} \mathrm{H} \mathrm{NMR}\left(300 \mathrm{MHz}, \mathrm{CDCl}_{3}\right): \delta=1.37(6 \mathrm{H}, \mathrm{t}, J=7.1 \mathrm{~Hz}), 2.27-2.55(7 / 10$ of $4 \mathrm{H}, \mathrm{m})$, 2.59-2.76 (3/10 of $4 \mathrm{H}, \mathrm{m}), 4.23-4.31\left(4 \mathrm{H}\right.$, pseudo $\left.\mathrm{p}, J_{\mathrm{HH}}=J_{\mathrm{PH}}=7.2 \mathrm{~Hz}\right), 4.90(2 \mathrm{H}, \mathrm{s}), 7.35$ $7.39(5 \mathrm{H}, \mathrm{m}), 8.03\left(3 / 10\right.$ of $1 \mathrm{H}$, br s, NH), $8.73(7 / 10$ of $1 \mathrm{H}, \mathrm{br} \mathrm{s}, \mathrm{NH}) ;{ }^{13} \mathrm{C}$ NMR $(125 \mathrm{MHz}$, $\left.\mathrm{CDCl}_{3}\right): \delta=16.4\left(\mathrm{CH}_{3} \times 2, \mathrm{~d}, J_{\mathrm{CP}}=5.5 \mathrm{~Hz}\right), 23.3-23.7\left(\mathrm{CH}_{2} \mathrm{CF}_{2}{ }^{*}, \mathrm{~m}\right), 24.7-25.3\left(\mathrm{CH}_{2} \mathrm{CF}_{2}, \mathrm{~m}\right)$, 28.0-28.7 $\left(\mathrm{CH}_{2} \mathrm{CO}^{*}, \mathrm{~m}\right), 29.7\left(\mathrm{CH}_{2} \mathrm{CO}, \mathrm{dt}, J_{\mathrm{CF}}=19.5 \mathrm{~Hz}, J_{\mathrm{CP}}=14.4 \mathrm{~Hz}\right), 64.3-65.0\left(\mathrm{CH}_{2} \times 2\right.$, m), $78.2\left(\mathrm{CH}_{2} \mathrm{Ph}\right), 79.4\left(\mathrm{CH}_{2} \mathrm{Ph}^{*}\right), 120.3\left(\mathrm{CF}_{2}, \mathrm{dt}, J_{\mathrm{CF}}=260.3 \mathrm{~Hz}, J_{\mathrm{CP}}=214.6 \mathrm{~Hz}\right), 128.6$ $\left(\mathrm{CH}_{\mathrm{ar}} \times 2\right), 128.7\left(\mathrm{CH}_{\mathrm{ar}}\right), 129.1\left(\mathrm{CH}_{\mathrm{ar}} \times 2\right), 135.3\left(\mathrm{C}_{\mathrm{ar}}\right), 168.9(\mathrm{CO}), 175.1\left(\mathrm{CO}^{*}\right) ;{ }^{19} \mathrm{~F}$ NMR $\left(282 \mathrm{MHz}, \mathrm{CDCl}_{3}\right): \delta=-112.52\left(\mathrm{~d}, J_{\mathrm{FP}}=109.0 \mathrm{~Hz}\right),-111.34\left(\mathrm{~d}, J_{\mathrm{FP}}=107.4 \mathrm{~Hz}\right) ;{ }^{31} \mathrm{P} \mathrm{NMR}$ $\left(121 \mathrm{MHz}, \mathrm{CDCl}_{3}\right): \delta=6.37\left(\mathrm{t}, J_{\mathrm{PF}}=107.1 \mathrm{~Hz}\right), 6.65\left(\mathrm{t}, J_{\mathrm{PF}}=106.5 \mathrm{~Hz}\right.$.

Diethyl 4-(N,N-benzyloxy-methyl)-amino-1,1-difluoro-4-oxobutyl phosphonate (19b). To a stirred solution of diethyl 4-(N-benzyloxy)-amino-1,1-difluoro-4-oxobutyl phosphonate 18 $(167 \mathrm{mg}, 0.5 \mathrm{mmol})$ in anhydrous acetone $(18 \mathrm{~mL})$ was added anhydrous $\mathrm{K}_{2} \mathrm{CO}_{3}(82 \mathrm{mg}$, $0.6 \mathrm{mmol})$. The reaction was stirred under reflux for $30 \mathrm{~min}$. Then, MeI (324 mg, $2.3 \mathrm{mmol}$ ) was added at room temperature and the solution was stirred overnight under reflux. The solution was filtered and evaporated to dryness under reduced pressure. The product was chromatographed on silica gel with gradient elution by EtOAc/PE 7:3 to 100\% EtOAc to give $19 \mathrm{~b}$ as a yellow oil (165 mg, $94 \%$ yield) and as a single conformer. $\mathrm{R}_{\mathrm{f}}=0.55$ (EtOAc); ${ }^{1} \mathrm{H}$ NMR $\left(500 \mathrm{MHz}, \mathrm{CDCl}_{3}\right): \delta=1.36(6 \mathrm{H}, \mathrm{t}, J=7.1 \mathrm{~Hz}), 2.32-2.44(2 \mathrm{H}, \mathrm{m}), 2.67-2.70(2 \mathrm{H}$, $\mathrm{m}), 3.20(3 \mathrm{H}, \mathrm{s}), 4.23-4.31(4 \mathrm{H}, \mathrm{m}), 4.84(2 \mathrm{H}, \mathrm{s}), 7.36-7.40(5 \mathrm{H}, \mathrm{m}) ;{ }^{13} \mathrm{C}$ NMR $(125 \mathrm{MHz}$, $\left.\mathrm{CDCl}_{3}\right): \delta=16.4\left(\mathrm{CH}_{3} \times 2, \mathrm{~d}, J_{\mathrm{CP}}=5.5 \mathrm{~Hz}\right), 24.0\left(\mathrm{CH}_{2} \mathrm{CO}\right), 28.9\left(\mathrm{CH}_{2} \mathrm{CF}_{2}, \mathrm{dt}, J_{\mathrm{CF}}=20.9 \mathrm{~Hz}\right.$, $\left.J_{\mathrm{CP}}=15.0 \mathrm{~Hz}\right), 33.75\left(\mathrm{CH}_{3} \mathrm{~N}\right), 64.5\left(\mathrm{CH}_{2} \times 2, \mathrm{~d}, J_{\mathrm{CP}}=6.7 \mathrm{~Hz}\right), 76.4\left(\mathrm{CH}_{2} \mathrm{Ph}\right), 120.4\left(\mathrm{CF}_{2}\right.$, $\left.\mathrm{dt}, J_{\mathrm{CF}}=257.7 \mathrm{~Hz}, J_{\mathrm{CP}}=215.2 \mathrm{~Hz}\right), 128.8\left(\mathrm{CH}_{\mathrm{ar}} \times 2\right), 129.1\left(\mathrm{CH}_{\mathrm{ar}}\right), 129.4\left(\mathrm{CH}_{\mathrm{ar}} \times 2\right), 134.2$ $\left(\mathrm{C}_{\mathrm{ar}}\right), 173.1(\mathrm{CO}) ;{ }^{19} \mathrm{~F}$ NMR $\left(282 \mathrm{MHz}, \mathrm{CDCl}_{3}\right): \delta=-113.39\left(\mathrm{~d}, J_{\mathrm{FP}}=108.1 \mathrm{~Hz}\right) ;{ }^{31} \mathrm{P} \mathrm{NMR}$ $\left(121 \mathrm{MHz}, \mathrm{CDCl}_{3}\right): \delta=7.07\left(\mathrm{t}, J_{\mathrm{PF}}=107.7 \mathrm{~Hz}\right) ; \mathrm{HRMS}\left(\mathrm{ESI}^{+}\right) \mathrm{m} / z$ calcd for $\mathrm{C}_{16} \mathrm{H}_{25} \mathrm{~F}_{2} \mathrm{NO}_{5} \mathrm{P}$ $[\mathrm{M}+\mathrm{H}]^{+}$380.1433, found 380.1445 . 
Diethyl 4-(N-hydroxyl)-amino-1,1-difluoro-4-oxobutyl phosphonate (20a) [21]. To a stirred solution of diethyl 4-(N-benzyloxy)-amino-1,1-difluoro-4-oxobutyl phosphonate 19a (217 $\mathrm{mg}, 0.6 \mathrm{mmol})$ in $\mathrm{MeOH}(15 \mathrm{~mL})$ was added $10 \% w / w$ Pd on activated carbon $(22 \mathrm{mg}, 0.02$ $\mathrm{mmol}$ ). The reaction flask was then connected to a balloon of $\mathrm{H}_{2}$ at atmospheric pressure. Every $20 \mathrm{~min}$, a slight vacuum was applied to the reaction flask, which was then backfilled with $\mathrm{H}_{2}$. When all starting material was consumed, the reaction was filtered over a pad of celite and evaporated to dryness under reduced pressure. The product was obtained pure in a quantitative yield (165 mg) as a colorless oil and as a mixture of two conformers $Z$ and $E$ in a 55:45 ratio respectively. $\mathrm{R}_{\mathrm{f}}=0.23\left(\right.$ EtOAc); ${ }^{1} \mathrm{H} \mathrm{NMR}\left(500 \mathrm{MHz}, \mathrm{CDCl}_{3}\right): \delta=1.37(6 \mathrm{H}$, $\mathrm{t}, J=7.0 \mathrm{~Hz}), 2.28-2.88(4 \mathrm{H}, \mathrm{m}), 4.28\left(4 \mathrm{H}\right.$, pseudo $\left.\mathrm{p}, J_{\mathrm{HH}}=J_{\mathrm{PH}}=7.1 \mathrm{~Hz}\right), 5.65(45 / 100 \mathrm{of}$ $1 \mathrm{H}$, br s, OH), 5.78 (55/100 of $1 \mathrm{H}$, br s, OH), 8.04 (45/100 of $1 \mathrm{H}$, br s, NH), 9.30 (55/100 of $1 \mathrm{H}$, br s, NH); ${ }^{13} \mathrm{C} \mathrm{NMR}\left(125 \mathrm{MHz} \mathrm{CDCl}_{3}\right): \delta=16.4\left(\mathrm{CH}_{3} \times 2, \mathrm{~d}, J_{\mathrm{CP}}=5.5 \mathrm{~Hz}\right), 24.7-24.9$ $\left(\mathrm{CH}_{2} \mathrm{CF}_{2}{ }^{*}, \mathrm{~m}\right), 27.2\left(\mathrm{CH}_{2} \mathrm{CF}_{2}, \mathrm{q}, J_{\mathrm{CF}}=4.8 \mathrm{~Hz}\right), 29.7\left(\mathrm{CH}_{2} \mathrm{CO}, \mathrm{dt}, J_{\mathrm{CF}}=21.3 \mathrm{~Hz}, J_{\mathrm{CP}}=16.2 \mathrm{~Hz}\right)$, $29.9\left(\mathrm{CH}_{2} \mathrm{CO}^{*}, \mathrm{dt}, J_{\mathrm{CF}}=21.3 \mathrm{~Hz}, J_{\mathrm{CP}}=16.2 \mathrm{~Hz}\right), 64.7\left(\mathrm{CH}_{2}^{*} \times 2, \mathrm{~d}, J_{\mathrm{CP}}=6.9 \mathrm{~Hz}\right), 65.0\left(\mathrm{CH}_{2}\right.$ $\left.\times 2, \mathrm{~d}, J_{\mathrm{CP}}=7.0 \mathrm{~Hz}\right), 120.2\left(\mathrm{CF}_{2}, J_{\mathrm{CF}}=257.5 \mathrm{~Hz}, J_{\mathrm{CP}}=216.0 \mathrm{~Hz}\right), 169.0\left(\mathrm{CO}^{*}\right), 173.3(\mathrm{CO})$; ${ }^{19} \mathrm{~F}$ NMR $\left(282 \mathrm{MHz}, \mathrm{CDCl}_{3}\right): \delta=-111.22\left(\mathrm{~d}, J_{\mathrm{FP}}=107.3 \mathrm{~Hz}\right),-112.69\left(\mathrm{~d}, J_{\mathrm{FP}}=107.7 \mathrm{~Hz}\right)$; ${ }^{31} \mathrm{P}$ NMR $\left(121 \mathrm{MHz}, \mathrm{CDCl}_{3}\right): \delta=6.31\left(\mathrm{t}, J_{\mathrm{PF}}=107.2 \mathrm{~Hz}\right), 6.52\left(\mathrm{t}, J_{\mathrm{PF}}=107.7 \mathrm{~Hz}\right)$.

Diethyl 4-(N,N-hydroxyl-methyl)-amino-1,1-difluoro-4-oxobutyl phosphonate (20b). To a stirred solution of diethyl 4-(N,N-benzyloxy-methyl)-amino-1,1-difluoro-4-oxobutyl phosphonate $19 \mathrm{~b}(120 \mathrm{mg}, 0.3 \mathrm{mmol})$ in $\mathrm{MeOH}(8 \mathrm{~mL})$ and water $(2.4 \mathrm{~mL})$ was added $10 \%$ $\mathrm{w} / \mathrm{w}$ Pd on activated carbon $(12 \mathrm{mg}, 0.01 \mathrm{mmol})$. The reaction flask was then connected to a balloon of $\mathrm{H}_{2}$ (1 atm). Every $20 \mathrm{~min}$, a slight vacuum was applied to the reaction flask, which was then backfilled with $\mathrm{H}_{2}$. When all starting material was consumed, the reaction was filtered over celite and evaporated to dryness under reduced pressure. The pure product was obtained as a light yellow oil (90 mg, quantitative yield) and as a mixture of conformers in a 6:4 ratio. $\mathrm{R}_{\mathrm{f}}=0.33(\mathrm{EtOAc}) ;{ }^{1} \mathrm{H} \mathrm{NMR}\left(500 \mathrm{MHz}, \mathrm{CDCl}_{3}\right): \delta=1.38(6 \mathrm{H}, \mathrm{t}$, $J=7.0 \mathrm{~Hz}), 2.29-2.51(2 \mathrm{H}, \mathrm{m}), 2.57-2.70(4 / 10$ of $2 \mathrm{H}, \mathrm{m}), 2.70-2.86(6 / 10 \mathrm{of} 2 \mathrm{H}, \mathrm{m}), 3.25$ (6/10 of $3 \mathrm{H}$, br s), $3.36\left(4 / 10\right.$ of $3 \mathrm{H}$, br s), 4.19-4.35 $\left(4 \mathrm{H}\right.$, pseudo $\left.\mathrm{p}, J_{\mathrm{HH}}=J_{\mathrm{PH}}=7.3 \mathrm{~Hz}\right)$; ${ }^{13} \mathrm{C}$ NMR $\left(125 \mathrm{MHz}, \mathrm{CDCl}_{3}\right): \delta=16.4\left(\mathrm{CH}_{3} \times 2, \mathrm{~d}, J_{\mathrm{CP}}=4.7 \mathrm{~Hz}\right), 22.8\left(\mathrm{CH}_{2} \mathrm{CO}^{*}\right), 24.0$ $\left(\mathrm{CH}_{2} \mathrm{CO}\right), 27.8-28.1\left(\mathrm{CH}_{2} \mathrm{CF}_{2}{ }^{*}, \mathrm{~m}\right), 29.0-30.3\left(\mathrm{CH}_{2} \mathrm{CF}_{2}, \mathrm{~m}\right), 35.7\left(\mathrm{CH}_{3} \mathrm{~N}^{*}\right), 36.1\left(\mathrm{CH}_{3} \mathrm{~N}\right), 64.7$ $\left(\mathrm{CH}_{2} \times 2, \mathrm{~d}, J_{\mathrm{CP}}=6.7 \mathrm{~Hz}\right), 65.0\left(\mathrm{CH}_{2}{ }^{*} \times 2, \mathrm{~d}, J_{\mathrm{CP}}=6.7 \mathrm{~Hz}\right), 119.9\left(\mathrm{CF}_{2}{ }^{*}, \mathrm{dt}, J_{\mathrm{CF}}=261.0 \mathrm{~Hz}\right.$, $\left.J_{\mathrm{CP}}=220.3 \mathrm{~Hz}\right), 120.3\left(\mathrm{CF}_{2}, \mathrm{dt}, J_{\mathrm{CF}}=261.0 \mathrm{~Hz}, J_{\mathrm{CP}}=220.3 \mathrm{~Hz}\right), 165.2\left(\mathrm{CO}^{*}\right), 171.5\left(\mathrm{CO}^{*}\right)$, $172.2(\mathrm{CO}), 173.6\left(\mathrm{CO}^{*}\right) ;{ }^{19} \mathrm{~F} \mathrm{NMR}\left(282 \mathrm{MHz}, \mathrm{CDCl}_{3}\right): \delta=-110.9\left(\mathrm{~d}, J_{\mathrm{FP}}=109.3 \mathrm{~Hz}\right)$, $-112.4\left(\mathrm{~d}, J_{\mathrm{FP}}=108.0 \mathrm{~Hz}\right),-113.4\left(\mathrm{~d}, J_{\mathrm{FP}}=105.9 \mathrm{~Hz}\right),-113.6\left(\mathrm{~d}, J_{\mathrm{FP}}=107.5 \mathrm{~Hz}\right){ }^{31} \mathrm{P} \mathrm{NMR}$ $\left(121 \mathrm{MHz}, \mathrm{CDCl}_{3}\right): \delta=6.61\left(\mathrm{t}, J_{\mathrm{PF}}=108.3 \mathrm{~Hz}\right), 6.75\left(\mathrm{t}, J_{\mathrm{PF}}=107.7 \mathrm{~Hz}\right) ; \mathrm{HRMS}\left(\mathrm{ESI}^{+}\right) \mathrm{m} / z$ calcd for $\mathrm{C}_{9} \mathrm{H}_{18} \mathrm{~F}_{2} \mathrm{NNaO}_{5} \mathrm{P}[\mathrm{M}+\mathrm{Na}]^{+} 312.0783$, found 312.0794.

(1,1-Difluoro-4-(hydroxyamino)-4-oxobutyl)phosphonic acid (10a). A solution of diethyl 4(N-hydroxyl)-amino-1,1-difluoro-4-oxobutyl phosphonate 20a $(25 \mathrm{mg}, 90.8 \mu \mathrm{mol})$ dissolved in DCM $(0.34 \mathrm{~mL})$ was cooled to $0{ }^{\circ} \mathrm{C}$. TMSBr $(0.12 \mathrm{~mL}, 0.9 \mathrm{mmol})$ was added dropwise at $0{ }^{\circ} \mathrm{C}$ then the reaction mixture was stirred overnight in the dark at room temperature. DCM and excess of TMSBr were evaporated under reduced pressure and the intermediate orange oil was treated with water $(0.5 \mathrm{~mL}, 27.8 \mathrm{mmol})$ for $1.5 \mathrm{~h}$. Removal of water under vacuum affords $10 \mathrm{a}$ as a light orange solid (20 mg, quantitative yield) and as a mixture of conformers. $\mathrm{R}_{\mathrm{f}}=0.4$ (EtOAc); ${ }^{1} \mathrm{H}$ NMR (400 MHz, CD $\left.\mathrm{CD}_{3} \mathrm{OD}\right): \delta=2.33-2.45(2 \mathrm{H}, \mathrm{m}), 2.50-2.53$ $(4 / 10$ of $2 \mathrm{H}, \mathrm{m}), 2.60(6 / 10$ of $2 \mathrm{H}, \mathrm{t}, J=7.5 \mathrm{~Hz}) ;{ }^{13} \mathrm{C}$ NMR $\left(125 \mathrm{MHz}, \mathrm{CD}_{3} \mathrm{OD}\right): \delta=26.9-27.1$ $\left(\mathrm{CH}_{2} \mathrm{CF}_{2}, \mathrm{~m}\right), 28.0-28.1\left(\mathrm{CH}_{2} \mathrm{CF}_{2}{ }^{*}, \mathrm{~m}\right), 30.3\left(\mathrm{CH}_{2} \mathrm{CO}, \mathrm{dt}, J_{\mathrm{CF}}=21.5 \mathrm{~Hz}, J_{\mathrm{CP}}=15.8 \mathrm{~Hz}\right), 30.6-$ $31.1\left(\mathrm{CH}_{2} \mathrm{CO}^{*}, \mathrm{~m}\right), 121.5\left(\mathrm{CF}_{2}, \mathrm{dt}, J_{\mathrm{CF}}=257.8 \mathrm{~Hz}, J_{\mathrm{CP}}=210.8 \mathrm{~Hz}\right), 174.2(\mathrm{CO}), 177.2\left(\mathrm{CO}^{*}\right)$; ${ }^{19} \mathrm{~F}$ NMR $\left(282 \mathrm{MHz}, \mathrm{CD}_{3} \mathrm{OD}\right): \delta=-116.6\left(\mathrm{~d}, J_{\mathrm{FP}}=104.6 \mathrm{~Hz}\right),-116.8\left(\mathrm{~d}, J_{\mathrm{FP}}=104.4 \mathrm{~Hz}\right)$, $-116.8\left(\mathrm{~d}, J_{\mathrm{FP}}=104.1 \mathrm{~Hz}\right) ;{ }^{31} \mathrm{P}$ NMR $\left(162 \mathrm{MHz}, \mathrm{CD}_{3} \mathrm{OD}\right): \delta=5.12\left(\mathrm{t}, J_{\mathrm{PF}}=104.0 \mathrm{~Hz}\right), 5.21(\mathrm{t}$, $\left.J_{\mathrm{PF}}=104.4 \mathrm{~Hz}\right), 5.32\left(\mathrm{t}, J_{\mathrm{PF}}=104.9 \mathrm{~Hz}\right) ; \mathrm{HRMS}\left(\mathrm{ESI}^{+}\right) \mathrm{m} / z$ calcd for $\mathrm{C}_{4} \mathrm{H}_{9} \mathrm{~F}_{2} \mathrm{NO}_{5} \mathrm{P}[\mathrm{M}+\mathrm{H}]^{+}$ 220.0181, found 220.0192 .

(1,1-Difluoro-4-(hydroxy(methyl)amino)-4-oxobutyl)phosphonic acid (10b). A solution of diethyl 4-(N,N-hydroxyl-methyl)-amino-1,1-difluoro-4-oxobutyl phosphonate $20 \mathrm{~b}$ (20 mg, $69.2 \mu \mathrm{mol})$ dissolved in DCM $(0.26 \mathrm{~mL})$ was cooled to $0^{\circ} \mathrm{C}$. TMSBr $(0.10 \mathrm{~mL}, 0.7 \mathrm{mmol})$ 
was added dropwise at $0{ }^{\circ} \mathrm{C}$ then the reaction mixture was stirred overnight in the dark at room temperature. DCM and excess of TMSBr were evaporated under reduced pressure and the intermediate orange oil was treated with water $(0.5 \mathrm{~mL}, 27.8 \mathrm{mmol})$ for $1.5 \mathrm{~h}$. Removal of water under vacuum affords $\mathbf{1 0 b}$ as an orange oil (16 mg, quant. yield) and as a mixture of conformers. $\mathrm{R}_{\mathrm{f}}=0.1$ (EtOAc); ${ }^{1} \mathrm{H}$ NMR $\left(400 \mathrm{MHz}, \mathrm{CD}_{3} \mathrm{OD}\right): \delta=2.28-2.47(2 \mathrm{H}$, m), 2.56-2.63 (4/10 of $2 \mathrm{H}, \mathrm{m}), 2.74-2.78$ (6/10 of $2 \mathrm{H}, \mathrm{m}), 2.95$ (6/10 of $3 \mathrm{H}, \mathrm{s}), 3.21$ (4/10 of $3 \mathrm{H}, \mathrm{s}) ;{ }^{13} \mathrm{C}$ NMR $\left(125 \mathrm{MHz}, \mathrm{CD}_{3} \mathrm{OD}\right): \delta=25.0-25.2\left(\mathrm{CH}_{2} \mathrm{CF}_{2}{ }^{*}, \mathrm{~m}\right), 26.8-27.0\left(\mathrm{CH}_{2} \mathrm{CF}_{2}\right.$, $\mathrm{m}), 30.2\left(\mathrm{CH}_{2} \mathrm{CO}^{*}, \mathrm{dt}, J_{\mathrm{CF}}=19.9 \mathrm{~Hz}, J_{\mathrm{CP}}=15.7 \mathrm{~Hz}\right), 30.3\left(\mathrm{CH}_{2} \mathrm{CO}, \mathrm{dt}, J_{\mathrm{CF}}=21.2 \mathrm{~Hz}\right.$, $\left.J_{\mathrm{CP}}=15.7 \mathrm{~Hz}\right), 36.4\left(\mathrm{CH}_{3} \mathrm{~N}^{*}\right), 38.1\left(\mathrm{CH}_{3} \mathrm{~N}\right), 121.7\left(\mathrm{CF}_{2}, \mathrm{td}, J_{\mathrm{CF}}=258.4 \mathrm{~Hz}, J_{\mathrm{CP}}=212.1 \mathrm{~Hz}\right)$, $174.0\left(\mathrm{CO}^{*}\right), 174.2(\mathrm{CO}) ;{ }^{19} \mathrm{~F}$ NMR $\left(282 \mathrm{MHz}, \mathrm{CD}_{3} \mathrm{OD}\right): \delta=-118.1\left(\mathrm{~d}, J_{\mathrm{FP}}=104.1 \mathrm{~Hz}\right)$, $-118.4\left(\mathrm{~d}, J_{\mathrm{FP}}=104.1 \mathrm{~Hz}\right) ;{ }^{31} \mathrm{P}$ NMR $\left(162 \mathrm{MHz}, \mathrm{CD}_{3} \mathrm{OD}: \delta=5.21\left(\mathrm{t}, J_{\mathrm{PF}}=103.7 \mathrm{~Hz}\right), 5.33\right.$ $\left(\mathrm{t}, J_{\mathrm{PF}}=105.3 \mathrm{~Hz}\right), 5.48\left(\mathrm{t}, J_{\mathrm{PF}}=105.8 \mathrm{~Hz}\right)$; HRMS $\left(\mathrm{ESI}^{-}\right) \mathrm{m} / z$ calcd for $\mathrm{C}_{5} \mathrm{H}_{10} \mathrm{~F}_{2} \mathrm{NO}_{5} \mathrm{P}$ $[\mathrm{M}-\mathrm{H}]^{-}$232.0192, found 232.0206 .

\subsection{Biological Activity}

\subsubsection{His-Tagged DXR Activity}

The assays were performed at $37^{\circ} \mathrm{C}$ in a $50 \mathrm{mM}$ Tris $/ \mathrm{HCl}$ buffer $\mathrm{pH} 7.5$ containing $3 \mathrm{mM} \mathrm{MgCl}_{2}$ and $2 \mathrm{mM}$ DTT. The concentrations of DXP and NADPH were $480 \mu \mathrm{M}$ and $160 \mu \mathrm{M}$ respectively. The decrease of absorbance at $340 \mathrm{~nm}$ due to NADPH oxidation was monitored to determine the initial rates. The retained values were the average of at least two measurements. The relative average deviation must be lower than $4 \%$.

\subsubsection{Inhibition of His-Tagged DXR}

Fosmidomycin was purchased from Fujisawa Pharmaceutical. Inhibitor concentrations in the stock solutions were verified by spectrophotometric phosphorus determination [28]. The study compounds $\mathbf{9 b}$ and $\mathbf{1 0 a}, \mathbf{1 0 b}$ were tested against E. coli DXR using a photometric assay that was described earlier [8]. H-DXR was pre-incubated during 2 min in the presence of the inhibitors $9 \mathbf{b}, \mathbf{1 0 a}$ and $\mathbf{1 0 b}$ at different concentrations and NADPH. DXP was then added to measure the residual activity. The inhibitory potential of the tested compounds was quantified by determining the $\mathrm{IC}_{50}$ values. They were obtained by plotting the percentage of residual activity versus the Log of inhibitor concentration.

\subsubsection{Bacterial Growth Inhibition}

The antimicrobial activity of hydroxamic acids $9 \mathbf{b}, \mathbf{1 0 a}$ and $\mathbf{1 0 b}$ against E. coli XL1 Blue [8] and fosmidomycin-resistant strain E. coli FosR [7], was determined using the paper disc diffusion method. LB agar plates $(9 \mathrm{~cm}$ diameter) were inoculated with a suspension of bacteria ( $200 \mu \mathrm{L}$, mid-exponential phase). Paper discs (Durieux no. 268, diameter $6 \mathrm{~mm}$ ) impregnated with a volume $\leq 8 \mu \mathrm{L}$ of fosmidomycin derivatives were placed on Petri dishes. Growth inhibition was examined after $24 \mathrm{~h}$ incubation at $37^{\circ} \mathrm{C}$.

Supplementary Materials: The following are available online. ${ }^{1} \mathrm{H}-\mathrm{NMR},{ }^{13} \mathrm{C}-\mathrm{NMR},{ }^{19} \mathrm{~F}-\mathrm{NMR}$ and ${ }^{31} \mathrm{P}-\mathrm{NMR}$ spectra of compounds $\mathbf{5 - 2 0}$ are included.

Author Contributions: A.D., F.S.K., C.N. and M.M. are first coauthors contributing equally to the experiments. D.T. performed biological assays; Methodology, D.L.; Conceptualization, M.R., C.G.-B.; writing-original draft preparation, C.G.-B.; supervision, C.G.-B.; writing-review and editing, D.L., M.R., C.G.-B. All authors have read and agreed to the published version of the manuscript.

Funding: This research received no external funding.

Institutional Review Board Statement: Not applicable.

Informed Consent Statement: Not applicable.

Data Availability Statement: The data presented in this study are contained within the article and are also available in the Supplementary Materials. 
Acknowledgments: M.M. and F.K. acknowledge financial support from the 'Ministère de la Recherche' and M.M. in addition a partial support from the Foundation "Frontier Research in Chemistry" (Strasbourg, France). The authors express their gratitude to L. Allouche, B. Vincent and M. Coppe for NMR measurements.

Conflicts of Interest: The authors declare no conflict of interest.

Sample Availability: Not available.

\section{References}

1. Word Health Organisation. News Released 27 February 2017. Available online: https://www.who.int/news-room/detail/27-022017-who-publishes-list-of-bacteria-for-which-new-antibiotics-are-urgently-needed (accessed on 10 May 2020).

2. European Centre for Disease Prevention and Control. 15 November 2018. Available online: https:/ /www.ecdc.europa.eu/en/ publications-data/infographic-antibiotic-resistance-increasing-threat-human-health (accessed on 10 May 2020).

3. Rohmer, M.; Grosdemange-Billiard, C.; Seemann, M.; Tritsch, D. Isoprenoid biosynthesis as a novel target for antibacterial and antiparasitic drugs. Curr. Opin. Investig. Drugs 2004, 5, 154-162.

4. Okuhara, M.; Kuroda, Y.; Goto, T.; Okamoto, M.; Terano, H.; Kohsaka, M.; Aoki, H.; Imanaka, H. Studies on new phosphonic acid antibiotics. I. FR-900098, isolation and characterization. J. Antibiot. 1980, 33, 13-17. [CrossRef] [PubMed]

5. Okuhara, M.; Kuroda, Y.; Goto, T.; Okamoto, M.; Terano, H.; Kohsaka, M.; Aoki, H.; Imanaka, H. Studies on new phosphonic acid antibiotics. III., isolation and characterization of FR-31564, FR-32863 and FR-33289. J. Antibiot. 1980, 33, 24-28. [CrossRef]

6. Lanaspa, M.; Moraleda, C.; Machevo, S.; González, R.; Serrano, B.; Macete, E.; Cisteró, P.; Mayor, A.; Hutchinson, D.; Kremsner, P.G.; et al. Inadequate efficacy of a new formulation of fosmidomycin-clindamycin combination in Mozambican children less than three years old with uncomplicated Plasmodium falciparum malaria. Antimicrob. Agents Chemother. 2012, 56, 2923-2928. [CrossRef]

7. Hemmerlin, A.; Tritsch, D.; Hammann, P.; Rohmer, M.; Bach, T.J. Profiling of defense responses in Escherichia coli treated with fosmidomycin. Biochimie 2014, 99, 54-62. [CrossRef] [PubMed]

8. Kuntz, L.; Tritsch, D.; Grosdemange-Billiard, C.; Hemmerlin, A.; Willem, A.; Bach, T.J.; Rohmer, M. Isoprenoid biosynthesis as a target for antibacterial and antiparasitic drugs: Phosphonohydroxamic acids as inhibitors of deoxyxylulose phosphate reducto-isomerase. Biochem. J. 2005, 386, 127-135. [CrossRef]

9. Munier, M.; Tritsch, D.; Krebs, F.; Esque, J.; Hemmerlin, A.; Rohmer, M.; Stote, R.H.; Grosdemange-Billiard, C. Synthesis and biological evaluation of phosphate isosters of fosmidomycin and analogs as inhibitors of Escherichia coli and Mycobacterium smegmatis 1-deoxyxylulose 5-phosphate reductoisomerases. Bioorg. Med. Chem. 2017, 25, 684-689. [CrossRef]

10. Woo, Y.-H.; Fernandes, R.P.M.; Proteau, P.J. Evaluation of fosmidomycin analogs as inhibitors of the Synechocystis sp. PCC6803 1-deoxy-D-xylulose 5-phosphate reductoisomerase. Bioorg. Med. Chem. 2006, 14, 2375-2385. [CrossRef] [PubMed]

11. Nieschalk, J.; O'Hagan, D. Monofluorophosphonates as phosphate mimics in bioorganic chemistry: A comparative study of $\mathrm{CH}_{2}-$, $\mathrm{CHF}$ - and $\mathrm{CF}_{2}$-phosphonate analogues of $s n$-glycerol-3-phosphate as substrates for sn-glycerol-3-phosphate dehydrogenase. J. Chem. Soc. Chem. Commun. 1995, 7, 719-720. [CrossRef]

12. Nieschalk, J.; Batsanov, A.S.; O'Hagan, D.; Howard, J. Synthesis of monofluoro- and difluoro-methylenephosphonate analogues of sn-glycerol-3-phosphate as substrates for glycerol-3-phosphate dehydrogenase and the X-ray structure of the fluoromethylenephosphonate moiety. Tetrahedron 1996, 52, 165-176. [CrossRef]

13. Romanenko, V.D.; Kukhar, V.P. Fluorinated phosphonates: Synthesis and biomedical application. Chem. Rev. 2006, 106, 3868-3935. [CrossRef] [PubMed]

14. Verbrugghen, T.; Cos, P.; Maes, L.; Van Calenbergh, S. Synthesis and evaluation of -halogenated analogues of 3(acetylhydroxyamino)propylphosphonic acid (FR-900098) as antimalarials. J. Med. Chem. 2010, 53, 5342-5346. [CrossRef]

15. Berkowitz, D.B.; Bose, M. ( $\alpha$-Monofluoroalkyl)phosphonates: A class of isoacidic and "tunable" mimics of biological phosphates. J. Fluor. Chem. 2001, 112, 13-33. [CrossRef]

16. Blackburn, G.M.; England, D.A.; Kolkmann, F. Monofluoro- and difluoro-methylenebisphosphonic acids: Isopolar analogues of pyrophosphoric acid. J. Chem. Soc. Chem. Commun. 1981, 17, 930-932. [CrossRef]

17. Blackburn, G.M.; Kolkmann, F. The synthesis and metal binding characteristics of novel, isopolar phosphonate analogues of nucleotides. J. Chem. Soc. Perkin Trans. 1984, 1, 1119-1125. [CrossRef]

18. Berkowitz, D.B.; Eggen, M.J.; Shen, Q.; Shoemaker, R.K. Ready access to fluorinated phosphonate mimics of secondary phosphates. Synthesis of the ( $\alpha, \alpha$-difluoroalkyl)phosphonate analogues of L-phosphoserine, L-phosphoallothreonine, and L-phosphothreonine. J. Org. Chem. 1996, 61, 4666-4675. [CrossRef]

19. Gillis, E.P.; Eastman, K.J.; Hill, M.D.; Donnelly, D.J.; Meanwell, N.A. Applications of fluorine in medicinal chemistry. J. Med. Chem. 2015, 58, 8315-8359. [CrossRef]

20. Shah, P.; Westwell, A.D. The role of fluorine in medicinal chemistry. J. Enzyme Inhib. Med. Chem. 2007, 22, 527-540. [CrossRef] [PubMed]

21. Volle, J.-N.; Midrier, C.; Blanchard, V.; Braun, R.; Haaf, K.; Willms, L.; Pirat, J.-L.; Virieux, D. Preparation of gem-difluorinated retrohydroxamic-fosmidomycin. ARKIVOC-Online J. Org. Chem. 2015, 2015, 117-126. [CrossRef]

22. Yokomatsu, T.; Suemune, K.; Murano, T.; Shibuya, S. Synthesis of ( $\alpha, \alpha$-difluoroallyl)phosphonates from alkenyl halides or acetylenes. J. Org. Chem. 1996, 61, 7207-7211. [CrossRef] 
23. Chambers, R.D.; Jaouharl, R.; O'Hagan, D. Fluorine in enzyme chemistry part 2. The preparation of difluoromethylenephosphonate analogues of glycolytic phosphates. Approaching an isosteric and isoelectronic phosphate mimic. Tetrahedron 1989, 45, 5101-5108. [CrossRef]

24. Brown, D.A.; Glass, W.K.; Mageswaran, R.; Girmay, B. cis-trans Isomerism in monoalkylhydroxamic acids by ${ }^{1} \mathrm{H},{ }^{13} \mathrm{C}$ and ${ }^{15} \mathrm{~N}$ NMR spectroscopy. Magn. Reson. Chem. 1988, 26, 970-973. [CrossRef]

25. Brown, D.A.; Glass, W.K.; Mageswaran, R.; Mohammed, S.A. ${ }^{1} \mathrm{H}$ and ${ }^{13} \mathrm{C}$ NMR studies of isomerism in hydroxamic acids. Magn. Reson. Chem. 1991, 29, 40-45. [CrossRef]

26. O'Hagan, D. Understanding organofluorine chemistry. An introduction to the C-F bond. Chem. Soc. Rev. 2008, 37, 308-319. [CrossRef] [PubMed]

27. Zinglé, C.; Kuntz, L.; Tritsch, D.; Grosdemange-Billiard, C.; Rohmer, M. Isoprenoid biosynthesis via the methylerythritol phosphate pathway: Structural variations around phosphonate anchor and spacer of fosmidomycin, a potent inhibitor of deoxyxylulose phosphate reductoisomerase. J. Org. Chem. 2010, 75, 3203-3207. [CrossRef]

28. van den Bos, L.J.; Codée, J.D.C.; van der Toorn, J.C.; Boltje, T.J.; van Boom, J.H.; Overkleeft, H.S.; van der Marel, G. Thioglycuronides: Synthesis and application in the assembly of acidic oligosaccharides. Org. Lett. 2004, 6, 2165-2168. [CrossRef]

29. Lowry, O.H.; Lopez, J.A. The determination of inorganic phosphate in the presence of labile phosphate esters. J. Biol. Chem. 1946, 162, 421-428. [CrossRef]

30. Massey, R.C.; Buckling, A.; Peacock, S.J. Phenotypic switching of antibiotic resistance circumvents permanent costs in Staphylococcus aureus. Curr. Biol. 2001, 11, 1810-1814. [CrossRef]

31. Hikishima, S.; Hashimoto, M.; Magnowska, L.; Bzowska, A.; Yokomatsu, T. Structural-based design and synthesis of novel 9-deazaguanine derivatives having a phosphate mimic as multi-substrate analogue inhibitors for mammalian PNPs. Bioorg. Med. Chem. 2010, 18, 2275-2284. [CrossRef]

32. Chambers, R.D.; Jaouhari, R.; O'Hagan, D. Fluorine in enzyme chemistry: Part 1. Synthesis of difluoromethylene- phosphonate derivatives as phosphate mimics. J. Fluor. Chem. 1989, 44, 275-284. [CrossRef] 